\title{
Influence of fly ash, glass fibers and wastewater on production of recycled aggregate concrete
}

\author{
$\oplus$ A. Raza ${ }^{\mathrm{a}}, \oplus$ B. Ali ${ }^{\mathrm{b}}, \oplus \mathrm{F} . \mathrm{U} . \mathrm{Haq}^{\mathrm{c}}, \oplus \mathrm{M}$. Awais $^{\mathrm{d}}, \oplus \mathrm{M} . \mathrm{S}$. Jameel ${ }^{\mathrm{e}}$ \\ a. Department of Civil Engineering, University of Engineering and Technology, (Taxila, Pakistan) \\ b. Department of Civil Engineering, COMSATS University Islamabad Sahiwal Campus, (Sahiwal, Pakistan) \\ c. Centre of Excellence in Water Resources Engineering, University of Engineering and Technology, (Lahore, Pakistan) \\ d. Department of Business Administration, Institute of Southern Punjab, (Multan, Pakistan) \\ e. Department of Transportation Engineering and Management, University of Engineering and Technology, (Lahore, Pakistan) \\ aliraza@piet.edu.pk
}

Received 14 December 2020

Accepted 1 March 2021

Available on line 17 August 2021

\begin{abstract}
To encounter the issues of waste materials, low tensile strength of concrete and environmental impacts of cement production, research is needed to develop a sustainable concrete. This study has endeavored to investigate the effects of using recycled coarse aggregates (RCA), various types of wastewater effluents, fly ash, and glass fibers on the mechanical and durability behavior of recycled aggregate concrete (RAC) incorporating with fly ash and glass fibers (FGRAC). Six different kinds of wastewater effluents for the mixing of concrete, $100 \%$ replacing the natural coarse aggregates with RCA, and $30 \%$ replacement of cement with fly ash were used for the development of concrete. The experimental measurement portrayed that the textile factory effluent presented the highest compressive and tensile strengths of concrete. Fertilizer factory effluent portrayed the highest water absorption, mass loss due to acid attack, and chloride penetration to concrete.
\end{abstract}

KEYWORDS: Recycled aggregate concrete; Fly ash; Wastewater; Compressive strength; Chloride penetration.

Citation/Citar como: Raza, A.; Ali, B.; Haq, F.U.; Awais, M.; Jameel, M.S. (2021) Influence of fly ash, glass fibers and wastewater on production of recycled aggregate concrete. Mater. Construcc. 72 [343], e253. https://doi.org/10.3989/mc.2021.15120.

RESUMEN: Influencia de las cenizas volantes, las fibras de vidrio y las aguas residuales en la producción de hormigón con árido reciclado. Para enfrentar los problemas de los materiales de desecho, la baja resistencia a la tracción del hormigón y los impactos ambientales de la producción de cemento, se necesita investigación para desarrollar un hormigón sostenible. Este estudio investiga los efectos del uso de áridos gruesos reciclados (RCA), varios tipos de efluentes de aguas residuales, cenizas volantes y fibras de vidrio sobre el comportamiento mecánico y la durabilidad del hormigón con árido reciclado (RAC), incorporando cenizas volantes y fibras de vidrio (FGRAC). Para el desarrollo del hormigón se utilizaron seis tipos diferentes de efluentes de aguas residuales, se sustituyó el 100\% de los áridos gruesos naturales por RCA y el 30\% del cemento por cenizas volantes. Se comprobó que el empleo de efluente de fábrica textil promovió la mayor resistencia a la compresión y a la tracción del hormigón. El empleo del efluente de la fábrica de fertilizantes presentó la mayor absorción de agua, pérdida de masa debido al ataque de ácido y penetración de cloruro en el hormigón.

PALABRAS CLAVE: Hormigón con árido reciclado; Cenizas volantes; Aguas residuales; Resistencia a compresión; Penetración de cloruros.

Copyright: C2021 CSIC. This is an open-access article distributed under the terms of the Creative Commons Attribution 4.0 International (CC BY 4.0) License. 


\section{INTRODUCTION}

The construction industry is generating a large quantity of construction and demolishing waste in the form of concrete waste which needs to be properly managed for sustainable development. The application of concrete waste in the form of recycled aggregate concrete (RAC) minimizes the requirement of landfills for the demolition waste, and transportation costs of aggregates by preserving the natural resources, reclamation lands, and reducing the number of loads headed to landfills (1-6). Furthermore, the production of cement is increasing to meet the demand for concrete construction resulting in high carbon dioxide emissions. The impact of cement on the environment can be minimized by partially replacing it with fly ash. Additionally, a large portion of industrial and municipal wastewater is discharged into rivers and landfill sites. The environmental regulating agencies are following strict guidelines and denying a municipal landfill near cities. These agencies are enforcing pressure to identify an alternative way of disposal at a fair price. The rapid development in population and the increase in economic developments raised the demand for freshwater. Concrete requires one trillion gallons of water annually which is the second largest used material after water (7). Hence, the use of freshwater in construction industries and other sectors must be reduced to build an equilibrium between the demand and supply of freshwater (8). The half population of the world will be faced with a shortage of freshwater by 2025 (9). Researchers are emphasizing to reuse of wastewater, especially in concrete production. The wastewater can be used in the construction of concrete to minimize the high cost of its management (10).

It was concluded that RAC-produced concrete exhibits inferior characteristics as compared to traditional concrete $(5,11-14)$. Some findings indicate that when recycled coarse aggregate (RCA) is used as a substitute to natural coarse aggregate (NCA) then the compressive strength of concrete is reduced between 20 to $30 \%$ (15-17). Besides, the compressive strength is reduced by 20 to $25 \%$ when NCA is fully replaced with RCA by holding the quantity of cement and $\mathrm{W} / \mathrm{C}$ ratio constant (18). When RCA is collected from different resources, the difference in compressive strength is more pronounced due to the variance of aggregate properties (18-25). The mortar stuck with coarse aggregate often compromises the strength properties of recycled aggregate concrete (RAC). If $34 \%$ mortar is stuck to an aggregate of size 10 to $20 \mathrm{~mm}$ then the compressive strength of RAC is reduced up to $10 \%$ (22). In the first 180 days, concrete produced with biologically treated wastewater reported a $17 \% \mathrm{im}$ provement in compressive strength. Afterward, axial strength in the case of secondary treated wastewater tends to decrease by approximately $18 \%$ relative to primary treated wastewater. However, the water ab- sorption is higher, when secondary treated wastewater is used in concrete production (26).

After examining the behavior of concrete fabricated with cementitious wash water, Asadollahfardi et al. (27) reported that cement wash water can be successfully used for the production of good quality fresh concrete. Experimental results showed that concrete fabricated with cement wash water or a mixture of it and clean water was performed better as compared to that concrete developed with silica and water admixture (28). Another research conducted by Wasserman (29) found that the compressive strength of concrete enhanced when cementitious washout water is used in concrete production as compared to traditional concrete. The compression performance of concrete was explored by using three kinds of wastewater such as sewage water, groundwater, and potable water, Nikhil et al. (30) deduced that concrete showed maximum compressive strength when drinking water used. Rabie et al. (31) performed an experimental study on mechanical properties of concrete developed by using wet and dry sewage sludge observed that there was a minor difference in compressive strength values by replacing cement content with wastewater sludge at $5 \%, 10 \%$, and $15 \%$ (by weight of cement content), but compressive strength beyond that percentage tends to decrease by $61.6 \%$ and $68.5 \%$, correspondingly. Roychand et al. (32) investigated the mechanical performance of concrete developed by using steel slag collected from civic wastewater effluent plant and reported that after substituting the coarse aggregate with steel slag aggregate, the compressive capacity increased by $18 \%$ and $16.8 \%$ at 7 and 28 days curing, correspondingly. Research conducted by Saxena and Tembhurkar (33) reported that bioconcrete showed a decline in its properties by incorporating wastewater and steel slag which can be fixed by using microbiologically induced $\mathrm{CaCO}_{3}$. The tensile and compressive strength of bio-concrete was increased by $12.5 \%$ and $31.1 \%$ due to its reduced water absorption.

Many studies explore the performance of RAC with fly ash (34-40). These investigations depicted that the effect of fly ash in RAC was superior to that in natural aggregate concrete (NAC). Kurad et al. (41) studied the effect of replacing NCA with RCA and cement with fly ash. They concluded that the compressive strength of concrete decreased up to $3 \%$ when RCA was $100 \%$ replaced with RAC. $30 \%$ replacement of cement with fly ash reduced the strength of concrete up to $4 \%$. Moreover, the decrease in the compressive strength of concrete for the combined use of RCA and fly ash was less than their individual use due to the pozzolanic reaction of fly ash with the adhered cement paste of RCA. Some studies $(34,35,38,42)$ portrayed that the incorporation of fly ash to the RAC presented better performance as compared with NAC in terms of sorptivity, 
chloride ion migration, and water absorption, etc. The addition of glass fibers improved the compressive, split tensile, and flexural strengths of concrete due to the enhanced bridging effect of fibers in concrete (43-48). Xue et al. (49) explored the bonding behavior between the steel fibers and RAC manufactured with mineral admixtures (silica fume) and observed an improvement in the compressive strength of RAC due to a good bond between steel fibers and RAC. Furthermore, the incorporation of both silica fume and steel fibers significantly improved the performance of RAC at elevated temperatures.

\subsection{Scope and significance}

The contaminated wastewater is producing negative impacts on the natural atmosphere as well as on human health. Therefore, such adverse impacts on the environment and human health could be avoided up to a certain limit by using wastewater in the concrete mix. Furthermore, to overwhelm the low tensile strength of plain concrete and the high carbon footprint of the cement industry, the use of glass fibers and fly ash to concrete is beneficial. In this study, mechanical properties such as compressive strength and split tensile strength as well as durability properties i.e., water absorption, chloride penetration, and resistance against $\mathrm{H}_{2} \mathrm{SO}_{4}$ of the recycled aggregate concrete incorporating with fly ash and glass fibers (FGRAC) have been studied under different curing ages by employing six types of wastewater for mixing purpose such as domestic sewage wastewater (DSW), fertilizer factory wastewater (FFW), textile factory wastewater (TFW), sugar factory wastewater (SFW), leather factory wastewater (LFW), and service station wastewater (SSW). One concrete mix was manufactured with potable water without adding glass fibers and fly ash for the comparative analysis. A one-way variance analysis (ANOVA) study was conducted at the five percent significance level to determine the value of discrepancy between the different properties of FGRAC mixes.

\section{TESTING PROGRAM}

\subsection{Materials}

Ordinary Portland cement having grade 43 was employed for concrete production as per ASTM C150/ C150M (50). The physicochemical properties of cement are presented in Table 1. F type fly ash taken from DIRK Pozzoplast was used in the present study. The chemical and physical properties of fly ash were reported in Table 1 . The RCA was used by replacing $100 \%$ NCA. For this purpose, reinforced concrete columns and cylinders with ages of 1 to 2 years were crushed having a compressive strength ranging between $30 \mathrm{MPa}$ and $45 \mathrm{MPa}$. The recycled aggregate with a maximum size of $12 \mathrm{~mm}$ was obtained. In this study, Lawrancepur sand was used according to ASTM C33/C33M-18 (51). The physical and chemical properties of sand and RCA are mentioned in Table 2 and the sieves analysis graphs of both materials are presented in Figure 1. The alkali-resistant glass fibers were employed in the present study having a tensile strength of $1800 \mathrm{MPa}$ and a specific gravity of 2.65. Some of the main characteristics of glass fibers were reported in Table 3 . The RAC was manufactured with six various types of wastewater based on their origins and potable water. The clean water was fully relieved by each wastewater type. The chemical examination of each type of wastewater was carefully performed and mentioned in Table 4. Besides, the chemical properties of wastewater were comprehensively tested in the Pakistan Council of Research in Water Resources.

\subsection{Fabrication and testing of specimens}

To achieve an optimal saturation, the RCA was submerged in potable water for 10 minutes (58). Seven

TABLE 1. Chemical and physical features of cement.

\begin{tabular}{llllll}
\hline Physical properties & \multicolumn{5}{l}{ Chemical properties } \\
\hline Parameter & Cement & Fly ash & Component & Cement & Fly ash \\
\hline Consistency (\%) (52) & 29.2 & 28.6 & $\mathrm{SiO}_{2}(\%)$ & 22.3 & 60.4 \\
\hline Specific gravity (53) & 3.0 & 2.3 & $\mathrm{Al}_{2} \mathrm{O}_{3}(\%)$ & 5.7 & 26.7 \\
\hline Final setting time (mins) (54) & 235 & - & $\mathrm{SO}_{3}(\%)$ & 2.5 & 1.1 \\
\hline Initial setting time (mins) (54) & 110 & - & $\mathrm{MgO}(\%)$ & 5.3 & 0.8 \\
\hline Specific surface area $\left(\mathrm{m}^{2} / \mathrm{kg}\right)(55)$ & 330 & 423 & $\mathrm{CaO}(\%)$ & 59 & 4.2 \\
\hline Fineness (Blaine Test) $\left(\mathrm{cm}^{2} / \mathrm{g}\right)$ & 2770 & 2950 & $\mathrm{Fe}_{2} \mathrm{O}_{3}(\%)$ & 6.0 & 2.5 \\
\hline Compressive strength at 3 days $(\mathrm{MPa})(56)$ & 38.5 & - & $\mathrm{Loss}$ of ignition $(\%)$ & 2.9 & 4.2 \\
\hline Compressive strength at 28-days $(\mathrm{MPa})(56)$ & 42.5 & - & $\mathrm{K}_{2} \mathrm{O}(\%)$ & 0.8 & - \\
\hline Soundness (57) & $\mathrm{No}$ expansion & - & $\mathrm{Na}_{2} \mathrm{O}$ & $0.4 \%$ & 1.4 \\
\hline
\end{tabular}



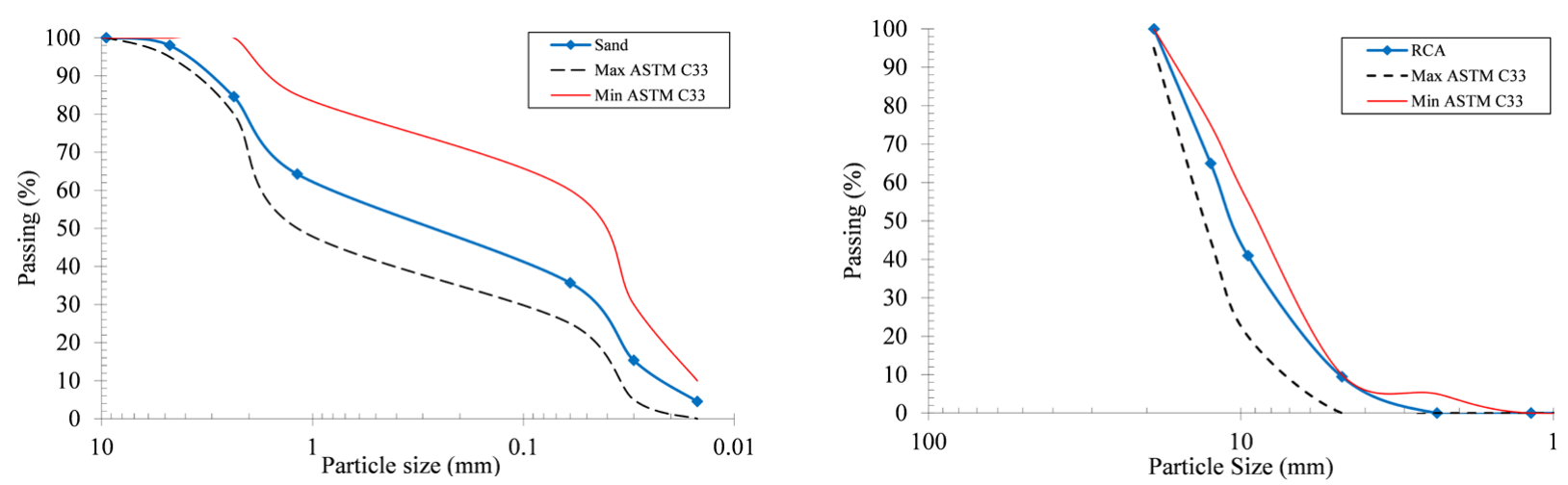

FIGURE 1. Granulometry of aggregates (left) fine aggregates (right) coarse aggregates.

TABLE 2. Various features of RCA and sand.

\begin{tabular}{lcc}
\hline \multicolumn{1}{c}{ Property } & Sand & RCA \\
\hline $\begin{array}{l}\text { Water absorption after } \\
\text { one day }(\%)\end{array}$ & 2.25 & 7.7 \\
\hline Fineness modulus & 2.45 & - \\
\hline Specific gravity & 2.62 & 2.25 \\
\hline Dry density $\left(\mathrm{kg} / \mathrm{m}^{3}\right)$ & 1650 & 1305 \\
\hline Maximum size $(\mathrm{mm})$ & 4.75 & 12.0 \\
\hline Minimum size $(\mathrm{mm})$ & - & 4.75 \\
\hline
\end{tabular}

TABLE 3. Characteristics of glass fibers.

\begin{tabular}{lclc}
\hline \multicolumn{1}{c}{ Parameter } & Value & Parameter & Value \\
\hline Diameter ( & 15 & Length $(\mathrm{mm})$ & $8-16$ \\
\hline Melting point $\left({ }^{\circ} \mathrm{C}\right)$ & 1000 & Texture $(\mathrm{g} / \mathrm{km})$ & 80 \\
\hline $\begin{array}{l}\text { Loss on ignition at } \\
900^{\circ} \mathrm{C}(\%)\end{array}$ & 1.15 & Moisture $(\%)$ & 0.4 \\
\hline Elastic modulus $(\mathrm{GPa})$ & 70 & $\begin{array}{l}\text { Tensile strength } \\
(\mathrm{MPa})\end{array}$ & 1800 \\
\hline Specific gravity & 2.65 & Density $\left(\mathrm{kg} / \mathrm{m}^{3}\right)$ & 890 \\
\hline
\end{tabular}

TABLE 4. Properties of different types of wastewater considered in the present work.

\begin{tabular}{lccccccc}
\hline \multicolumn{1}{c}{ Parameter (unit) } & PW & FFW & TFW & SSW & DSW & SFW & LFW \\
\hline pH value & 7.0 & 2.5 & 7.2 & 6.0 & 7.4 & 7.5 & 6.5 \\
\hline TDS (mg/l) & 761.6 & 2138 & 325.6 & 416.5 & 931.6 & 2712.2 & 387 \\
\hline TSS (mg/l) & 26.4 & 47.6 & 18.7 & 59.5 & 433.5 & 58.7 & 35.2 \\
\hline Turbidity (NTU) & 0.8 & 2.8 & 1.0 & 31.5 & 212.5 & 21.3 & 22.6 \\
\hline DO (mg/l) & 5.4 & 2 & 4.5 & 2.2 & 2.4 & 2.6 & 5.3 \\
\hline COD (mg/l) & 15.8 & 488.3 & 102 & 1207 & 357.9 & 807.5 & 1075 \\
\hline BOD $(\mathrm{mg} / \mathrm{l})$ & 10.4 & 518.5 & 59.5 & 952 & 264.4 & 612 & 852 \\
\hline Alkalinity $(\mathrm{mg} / \mathrm{l})$ & 69.8 & 1.4 & 40.8 & 73.1 & 82.5 & 104.6 & 23.5 \\
\hline Conductivity $(\mathrm{m}-\mathrm{s} / \mathrm{cm})$ & 1.2 & 7.3 & 0.6 & 0.7 & 1.6 & 5.7 & 1.4 \\
\hline Bicarbonates $(\mathrm{mg} / \mathrm{l})$ & 283.1 & 180 & 10.8 & 297.5 & 340 & 637.5 & 14.3 \\
\hline Hardness $(\mathrm{mg} / \mathrm{l})$ & 307.7 & 2176 & 290.7 & 314.5 & 612.9 & 1802 & 225.4 \\
\hline Sulphate $(\mathrm{mg} / \mathrm{l})$ & 6.2 & 807.5 & 89.3 & 98.6 & 641.8 & 178.5 & 74.6 \\
\hline Fluoride $(\mathrm{mg} / \mathrm{l})$ & 0.3 & 0.1 & 0.6 & 0.1 & 1 & 0.4 & 0.5 \\
\hline Nitrate $(\mathrm{mg} / \mathrm{l})$ & 1.2 & 56.1 & 2.4 & 8.5 & 86.7 & 27.2 & 2.2 \\
\hline Chloride $(\mathrm{mg} / \mathrm{l})$ & 10.4 & 892.5 & 53.9 & 212.5 & 289 & 732.7 & 183.4 \\
\hline Iron $(\mathrm{mg} / \mathrm{l})$ & 1.7 & 3.1 & 0.8 & 1.0 & 0.7 & 1.3 & 1.2 \\
\hline
\end{tabular}


TABLE 5. Quantities of different ingredients of various FGRAC mixes.

\begin{tabular}{|c|c|c|c|c|c|c|c|}
\hline \multirow{2}{*}{ Mix ID } & \multicolumn{2}{|c|}{ Mixing water } & \multirow{2}{*}{$\begin{array}{c}\text { Cement } \\
\left(\mathrm{kg} / \mathrm{m}^{3}\right)\end{array}$} & \multirow{2}{*}{$\begin{array}{l}\text { Fly ash } \\
\left(\mathrm{kg} / \mathrm{m}^{3}\right)\end{array}$} & \multirow{2}{*}{$\begin{array}{c}\text { Glass fibers } \\
\quad\left(\mathrm{kg} / \mathrm{m}^{3}\right)\end{array}$} & \multirow{2}{*}{$\begin{array}{c}\text { RCA } \\
\left(\mathrm{kg} / \mathrm{m}^{3}\right)\end{array}$} & \multirow{2}{*}{$\begin{array}{c}\text { Sand } \\
\left(\mathrm{kg} / \mathrm{m}^{3}\right)\end{array}$} \\
\hline & Type & Content $\left(\mathrm{kg} / \mathrm{m}^{3}\right)$ & & & & & \\
\hline PW30-GF-100RCA & Potable water & 233 & 466 & 94 & 12 & 1050 & 625 \\
\hline DS30-GF-100RCA & Domestic sewage & 233 & 372 & 94 & 12 & 1050 & 625 \\
\hline FF30-GF-100RCA & Fertilizer factory & 233 & 372 & 94 & 12 & 1050 & 625 \\
\hline TF30-GF-100RCA & Textile factory & 233 & 372 & 94 & 12 & 1050 & 625 \\
\hline SF30-GF-100RCA & Sugar factory & 233 & 372 & 94 & 12 & 1050 & 625 \\
\hline SS30-GF-100RCA & Service station & 233 & 372 & 94 & 12 & 1050 & 625 \\
\hline LF30-GF-100RCA & leather factory & 233 & 372 & 94 & 12 & 1050 & 625 \\
\hline
\end{tabular}

different types of FGRAC mixes i.e., potable drinking water mix (PW30-GF-100RCA), domestic sewage wastewater mix (DS30-GF-100RCA), fertilizer factory wastewater mix (FF30-GF-100RCA), textile factory wastewater mix (TF30-GF-100RCA), sugar factory wastewater mix (SF30-GF-100RCA), service station wastewater mix (SS30-GF-100RCA), and leather factory wastewater mix (LF30-GF-100RCA) were prepared. For comparative analysis, each of the FGRAC mixes was compared with the FGRAC mix prepared using potable water (PW) containing fly ash and glass fibers. The labeling of FGRAC mixes was done in such a way that the first two letters from the left side indicate the type of wastewater, the first digit from the left side indicates the percentage of fly ash, two letters at the middle indicate the addition of glass fibers, the digit from the right side indicates the $100 \%$ replacement of NCA with RCA, and three letters at the right side indicate recycled aggregate concrete (RAC).

A total of twenty-one cylindrical specimens (150 $\mathrm{mm} 300 \mathrm{~mm}$ ) from each wastewater (constant quantity) were prepared for the determination of compressive strength and splitting tensile strength. Three samples for each wastewater at all ages were prepared and tested. A total of forty-two specimens $(50 \mathrm{~mm}$ height and $100 \mathrm{~mm}$ in diameter) were developed for examining the waster absorption. For the determination of chloride ion migration, forty-two samples $(100 \mathrm{~mm}$ in diameter and $100 \mathrm{~mm}$ in height) were also prepared. Whereas, sixty-three cube samples of size $100 \mathrm{~mm}$ were cast to explore the resistance of FGRAC concrete against sulfuric acid attack. The ingredients and quantities utilized for each FGRAC blend as shown in Table 5.

A mixer at a speed of 20 revolutions/min (capacity of $0.15 \mathrm{~m}^{3}$ ) was used to mix concrete. A total of 10 minutes required for complete mixing. To achieve a homogenous mixture, the aggregate was mixed with water, fly ash, and cement in the first 5 minutes then added the remaining quantity of water and the glass fibers. For each wastewater mix, a slump test (as per ASTM/C143) was performed and its values ranging between $90 \mathrm{~mm}$ to $105 \mathrm{~mm}$ (59). For curing purposes, normal water was used in this study.
The properties such as compressive strength and split tensile strength for each RAC blend at different curing ages were tested. The compressive strength of specimens at 7, 28, and 90-days was tested according to ASTM C39 (60). On the other hand, the split tensile strength of specimens at 28 and 90-days was tested as per ASTM C496 (61). The strength properties such as chloride ion migration, water absorption, and acid attack were tested for all seven FGRAC blends. For the determination of water absorption, ASTM C1585 (62) was followed. All specimens at 28-days were placed at room temperature to find resistance against sulfuric acid $\left(\mathrm{H}_{2} \mathrm{SO}_{4}\right)$ left to dry at $50 \mathrm{C}^{\circ}$ for 24 hours then immersing them in $4 \% \mathrm{H}_{2} \mathrm{SO}_{4}$.

To find out how chloride ion penetrates, the specimens developed have been cured in water for 28 and 90-days, preceded by oven-drying at a temperature of $50^{\circ} \mathrm{C}$ for 24 hours. Following this, the specimens were cooled to normal temperature and then submerged in a solution of $4 \% \mathrm{NaCl}$ for 56 days. The splitting of cylinders procedure was followed as per the ASTM C496 (61) and spraying with a $1 \mathrm{~N} \mathrm{AgNO}_{3}$ solution into water. When $\mathrm{AgNO}_{3}$ reacts chemically with chloride ions, $\mathrm{AgCl}$ is produced giving a silver color.

\section{EXPERIMENTAL RESULTS AND DISCUS- SIONS}

\subsection{Compressive strength}

In this current investigation, the compressive strength for each of the six different FGRAC mixes was tested after 7, 28, and 90-days of curing as per ASTM C39 (60). Figure 2 reports the compressive strength of each varying FGRAC mix. Three developed samples of all RAC blends for each age group were placed compression test machine then their mean results were calculated. TF30-GF-100RCA mix recorded the maximum compressive strength while the DS30GF-100RCA mix displayed the lowest compressive strength at all the various testing ages. A control mix (PW30-GF-100RCA) has been developed to conduct a 
relative study of the results of different FGRAC mixtures produced using different kinds of wastewater. At 7-days, the compressive strength shown by PW30-GF100RCA was $18.45 \mathrm{MPa}$. The compressive strength at 28-days was $26 \mathrm{MPa}$ which was improved by $29 \%$ when compared with the measurement at 7-days. The compressive strength was $31.36 \mathrm{MPa}$ when checked at 90-days, which was $142 \%$ of the compressive strength observed at 7-days. Thus, the PW30-GF-100RCA mix with the testing age noted a significant rise in its compressive strength.

The compressive strength of concrete for the TF30GF-100RCA mix improved dramatically when compared with PW30-GF-100RCA at all ages. At 7-days, the TF30-GF-100RCA blend showed a compressive strength of $22.4 \mathrm{MPa}$ which was $17.6 \%$ higher as compared to the compressive strength of PW30-GF100RCA at 7-days. After 28-days, the compressive strength of the TF30-GF-100RCA mix was increased by $135 \%$ having a value of $34.6 \mathrm{MPa}$ which was $24.8 \%$ higher as compared to the compressive strength of the PW30-GF-100RCA mix. When bicarbonates and fluoride existing in TFW involves a reaction with $\mathrm{Al}_{2} \mathrm{O}_{3}$ remaining in ordinary Portland cement and thus proceed to calcium fluoroaluminate formation leading to the increased compressive strength of concrete. This mineral is extremely toxic, resulting in both fast setting and early hydration, which improved the performance (33). The high compressive strength of TF30-GF-100RCA than the control mix may also be ascribed to the addition of glass fibers and fly ash. Fly ash reduces the voids between fine particles and form CSH-gel after the chemical reaction of free $\mathrm{CH}$ and fly ash particles. Furthermore, the glass fibers provided the bridging effects between the particles of the TF30-GF-100RCA mix to improve the compressive strength.

The improved compressive strengths of FGRAC mixes developed with wastewater could be ascribed to the pozzolanic reactions between free fly ash and $\mathrm{CH}$. Fly ash filled the voids between sand and cement, improved the bond of glass fibers with the binding matrix, and, finally, formed a gel (C-S-H-gel) giving a stronger bond. Furthermore, the ability of glass fibers to prevent the propagation of cracks also improved the compressive strength of FGRAC mixes to give comparable results with the control mix.

By using FFW to produce FGRAC mixes, the compressive strength attained at 7-days was higher and lesser at 28 and 90-days associated with PW30GF-100RCA. At 7-days, the FF30-GF-100RCA mix exhibited a compressive strength of $21.2 \mathrm{MPa}$ that is $13 \%$ higher than the compressive strength of PW30GF-100RCA at 7-days. The compressive strength of the FF30-GF-100RCA mix was increased by $15.6 \%$ at 28-days having a value of $25.2 \mathrm{MPa}$. It was further decreased by $7.8 \%$ at 90 -days when compared with PW30-GF-100RCA but it showed $12.9 \%$ higher strength than at 28-days. This drop in the compressive strength of FF30-GF-100RCA mix at 28 and 90-days of testing occurred because of an increased quantity of COD as well as BOD at 5-days in FFW (63).

When DSW has been used for mixing, the compressive strength of concrete decreased considerably. At 7-day testing, the compressive strength was observed $11.9 \mathrm{MPa}$, at 28-days testing it was $18 \mathrm{MPa}$, and at 90-day testing, it was $15.3 \mathrm{MPa}$. The average compressive strengths were $35 \%, 30 \%$, and $51 \%$ lower than the strengths reported in the same order by the PW30-GF-100RCA mix at testing days of 7, 28, and 90. The uniformity of the mixing water has a significant effect on concrete strength. Consequently, the concrete strength for DS30-GF-100RCA is lower than PW30-GF-100RCA. While at 28-days of testing, this strength of the DS30-GF-100RCA mix increased to $34.3 \%$ and it shows a reduction of up to $15 \%$ at testing days of 90 . This reduction in the strength of the DS30GF-100RCA mix can be due to the existence of many organic matters in DSW that reacts with cement ingredients and thus result in reducing the strength of concrete. Due to the large amount of sulfate found in DSW, the compressive strength of the DS30-GF-100RCA mix is decreased after 90-days of testing.

When SSW was used for mixing, then the compression capacity of concrete was affected to a slight extent. It had shown compressive strengths of $16.9 \mathrm{MPa}$ in 7-days, 23.9 MPa in 28-days, and 29.8 $\mathrm{MPa}$ in 90 test days. These compressive strengths were in similar accordance with that of the PW30-GF-100RCA mix and on average $8.4 \%, 8 \%$, and $4.8 \%$ were lower than compressive strengths displayed by the PW30GF-100RCA mix at the testing days of 7, 28, and 90 . These negligible variations indicate that the concrete compressive strength has no noticeable effect when SSW is used for mixing. The reason is that SS30-GF100RCA has shown a decline in strength at all test ages which can be due to the existence of BOD and COD in excessive amounts. The concrete compressive strength decreased at 7-days by using SFW comparison to the PW30-GF-100RCA mix, which subsequently increased to $43.9 \%$ after 28 -day testing. SF30-GF100RCA mix has shown increased strength because of the long setting time of cement paste and the larger surface area of cement particles (64). Compared with the PW30-GF-100RCA mix, the concrete compressive strength decreased by $5 \%$ at 90 -days. This drop in the compression capacity can be due to the availability of $\mathrm{C}_{3} \mathrm{~S}$ in cement triggering the hydration process to delay $(65,66)$. Figure 3 represents the comparative strengths of all RAC blends at 7, 28, and 90 test days.

When LFW was used for mixing, then the compression capacity of concrete was affected to a slight extent. It had shown compressive strengths of 16.7 $\mathrm{MPa}$ in 7-days, 29.9 $\mathrm{MPa}$ in 28-days, and $30.5 \mathrm{MPa}$ in 90 test days. These compressive strengths were in similar accordance with that of the PW30-GF-100RCA mix and on average $9.5 \%, 3.3 \%$, and $7 \%$ lower than compressive strengths displayed by the PW30-GF100RCA mix at the testing days of 7,28, and 90. These 


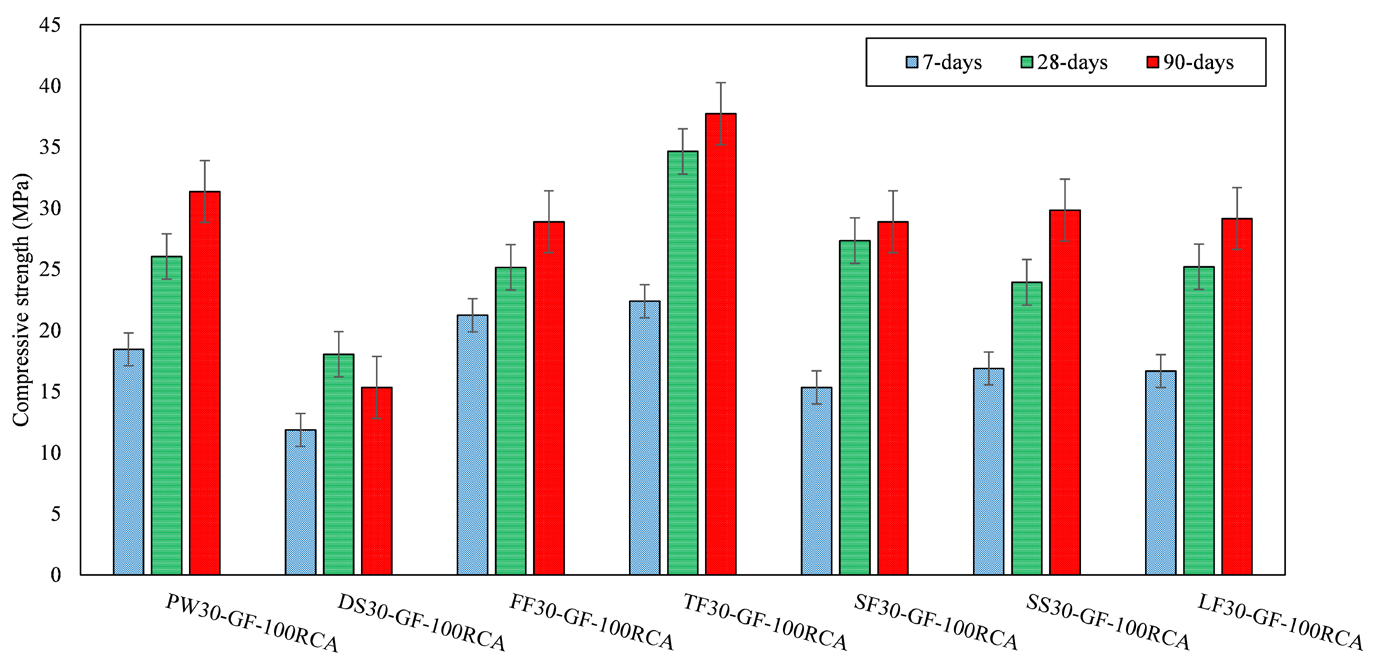

FigurE 2. Compressive strengths of FGRAC mix at 7, 28, and 90-days.

negligible variations indicate that the concrete compressive strength has no noticeable effect when LFW is used for mixing. The reason is that LF30-GF-100RCA has shown a decline in strength at all test ages that may be associated with a large amount of COD and BOD in LFW. The improved compressive strengths of FGRAC mixes fabricated with wastewater could be ascribed to the pozzolanic reactions between free $\mathrm{CH}$ and fly ash. Fly ash filled the voids between sand and cement, improved the bond of glass fibers with the binding matrix, and, finally, formed a gel (CSH-gel) giving a stronger bond. Furthermore, the ability of glass fibers to prevent the propagation of cracks also improved the compressive strength of FGRAC mixes to give comparable results with the control mix.

\subsection{Split tensile strength}

Figure 4 demonstrates the split tensile behavior of various FGRAC mixes that have been manufactured using different wastewater types. The specimens were tested following ASTM C496 (61). The PW30-GF100RCA mix displayed an average tensile strength of $2.45 \mathrm{MPa}$ at 7-days, 2.85 $\mathrm{MPa}$ at 28-days, and 3.46 $\mathrm{MPa}$ at 90-days, respectively indicating that the PW30GF-100RCA mix displayed a split tensile strength of $117 \%$ at 90 -days compared to its strength at 28-days. The TF30-GF-100RCA mix showed significantly higher split tensile strength whereas the DS30-GF100RCA mix showed the lowest strength. The TF30GF-100RCA mix displayed improved split tensile strengths of 2.84 MPa after 7-days, 3.6 MPa after 28days and 4.1 $\mathrm{MPa}$ at 90-days that were $13.7 \%, 20.8 \%$, and $15.6 \%$ greater than the PW30-GF-100RCA mix tested at various days, respectively. The tensile strength displayed by the TF30-GF-100RCA mix was greater as the TFW has lesser bicarbonates amounts relative to other wastewater types. After all, the rise in bicarbon- ates contributes to reduced tensile strength (67). The improved split tensile behavior of FGRAC mixes may be attributed to the pozzolanic reactions between free fly ash and CH. Fly ash forms the C-S-H-gel and fills the small voids between the fine aggregates and binder particles. Furthermore, the ability of glass fibers to prevent the propagation of cracks and to produce the bridging effect also improved the split tensile strength of FGRAC mixes to give comparable results with the control mix PW30-GF-100RCA.

The FF30-GF-100RCA mix indicated split tensile strengths of 2.36 MPa at 7-days, 2.68 MPa at 28-days, and $3.17 \mathrm{MPa}$ at 90-days, respectively. This indicates that the split tensile strengths were reduced by $3.6 \%$ at 7 -days, by $5.9 \%$ at 28 -days, and by $8.4 \%$ at 90 days associated with the control mix when FFW was used for mixing. The tensile strengths demonstrated by the DS30-GF-100RCA mix were small with falls of $8.9 \%$ at 7 -days, $7 \%$ at 28 -days, and $9.8 \%$ at 90 days as compared with the PW30-GF-100RCA mix. The SF30-GF-100RCA mix displayed split tensile strengths of 2.34 MPa at 7-days, 2.71 MPa at 28-days, and $3.29 \mathrm{MPa}$ at 90 -days with a reduction of $4.5 \%$ at 7 -days, $5.0 \%$ at 28 -days, and $4.8 \%$ at 90 -days, respectively. The decreases in split tensile strengths displayed by diverse FGRAC mixes (i.e. FF30-GF100RCA， DS30-GF-100RCA， SS30-GF-100RCA, and SF30-GF-100RCA) can be due to the excess of total suspended solids, COD, and BOD in such kinds of wastewater (68). The concrete displays a reduction in the tensile strength when the volume of chloride increases (69). This is due to the presence of large quantities of chloride. These FGRAC mixes have lower $\mathrm{pH}$ values. The reduction of the $\mathrm{pH}$ value is responsible for reducing the strength of the split tensile (70).

Figure 5 shows the comparison between the relative percentage of split tensile strengths produced by various FGRAC mixes and that reported by the PW30-GF- 


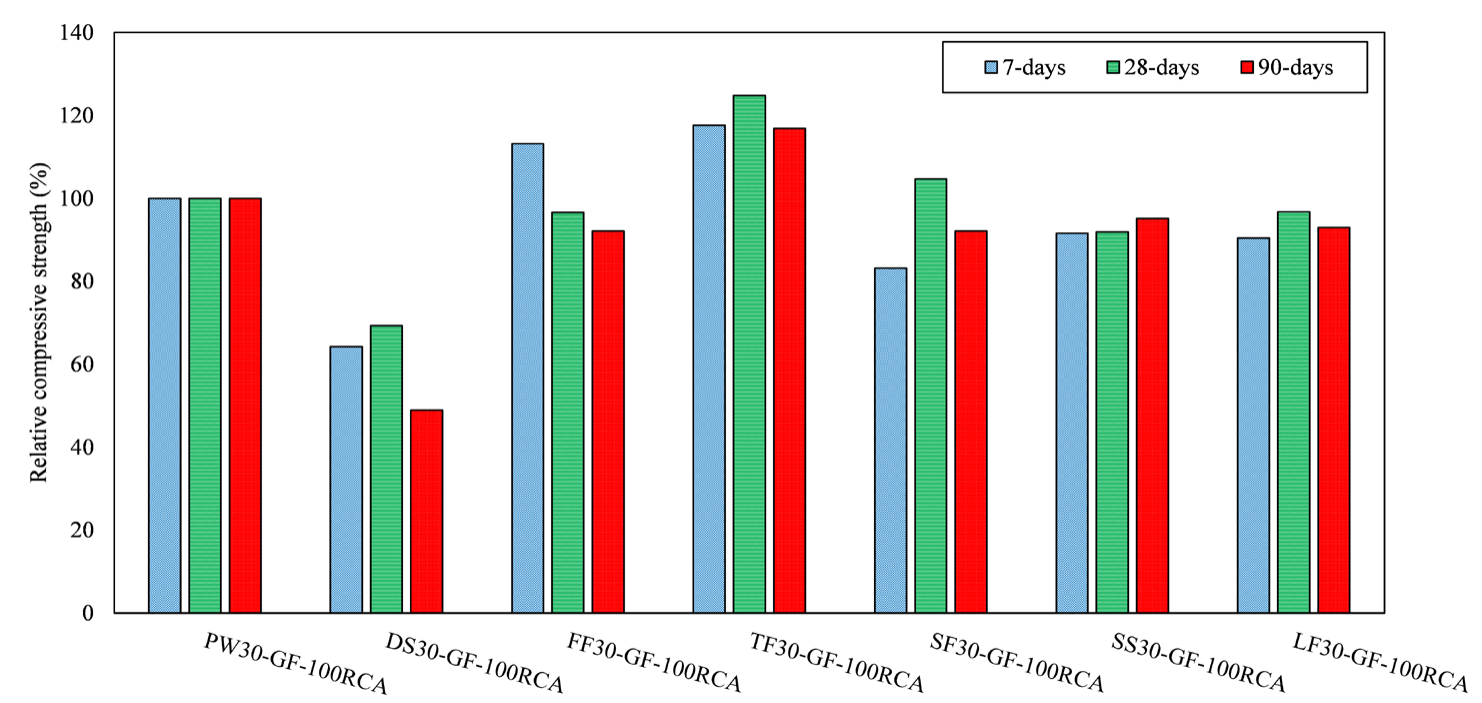

FIGURE 3. Relative comparative compressive strengths of FGRAC mix at 7, 28, and 90-days compared with control mix.

100RCA mix for different age groups. The LF30-GF100RCA mix displayed enhanced split tensile strengths of 2.89 $\mathrm{MPa}$ after 7-days, $3 \mathrm{MPa}$ after 28-days, and 3.4 $\mathrm{MPa}$ at 90-days that were on average $15.2 \%$ and $5.6 \%$ greater than the PW30-GF-100RCA mix experienced at 7 and 28-days, respectively. While this mix presented a $2 \%$ lower value of split tensile strength at 90-days compared with the PW30-GF-100RCA mix. The tensile strength displayed by the LF30-GF-100RCA mix was greater as the LFW has lesser bicarbonates amounts relative to other wastewater types because the rise in bicarbonates results in the reduced tensile behavior of concrete (67).

\subsection{Water absorption}

Being a durability parameter, the water absorption calculates the number of pores that are moisture-accessible in concrete. If water absorption is extreme, it will cause reinforcement corrosion which leads to the penetration of numerous toxic chemicals and when react with cement additives thus completely change the characteristics of concrete. Figure 6 indicates the water absorption shown by different RAC blends. Nearly all the specimens displayed relatively higher water absorption levels. This may be due to higher water absorption levels for RCA $(7.7 \%)$. When the findings were analyzed, they demonstrated that the different types of wastewater had no significant impact on concrete water absorption as shown in the literary works (71).

Different FGRAC mixes reported a reduction in the properties of water absorption with time. The water absorption shown by the PW30-GF-100RCA mix

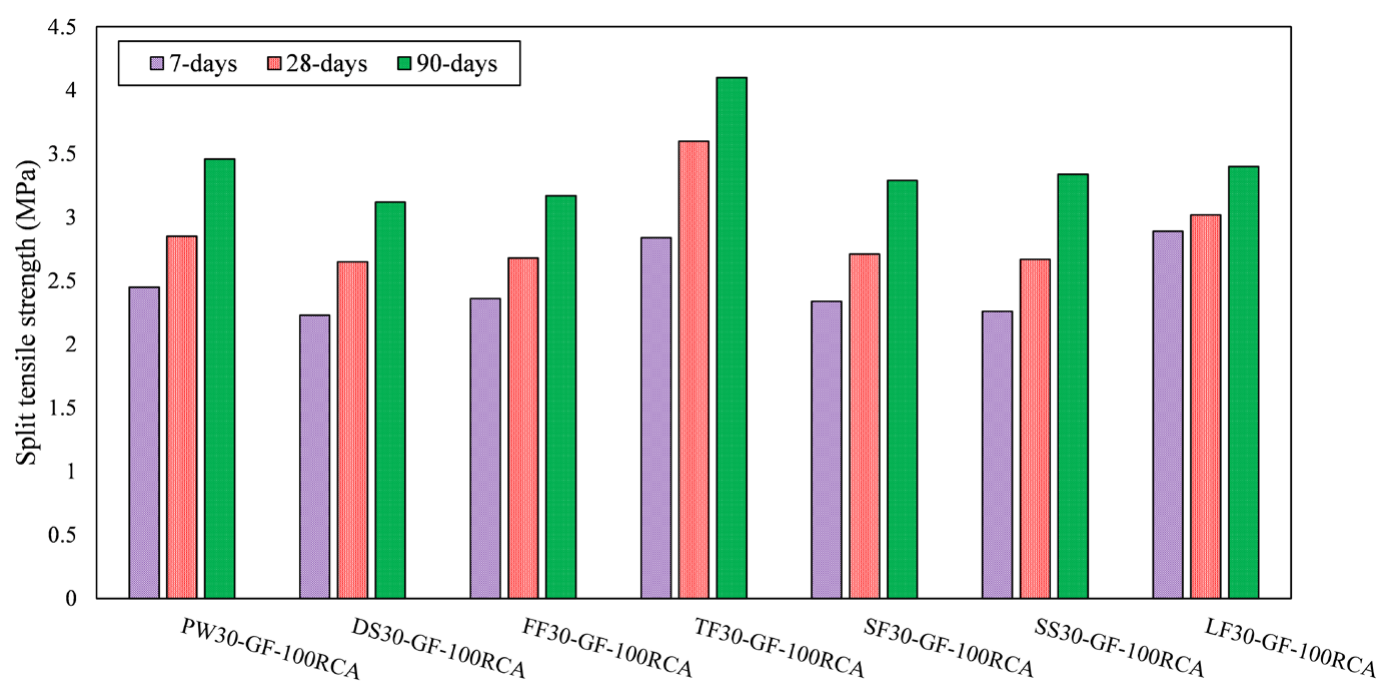

FIGURE 4. Split tensile strength of FGRAC mixes at 7, 28, and 90-days. 
was $12.5 \%$ at 28 -days and $9.2 \%$ at 90 -days, representing the decline in moisture content over time. As compared to PW30-GF-100RCA, the water absorption shown by the TF30-GF-100RCA mix was lower. The moisture content was $99 \%$ at 28 -days and $98 \%$ at 90-days equated to PW30-GF-100RCA. The decline in water absorption may be attributed to a reduction in the amount of chloride, as the volume of chloride rises, the concrete density lessens with reduced strengths plus enhanced porosity in concrete (69).

When tested at 28 and 90-days, correspondingly, the water absorption values of the FF30-GF-100RCA mix were $9.7 \%$ and $16.5 \%$ higher than that of PW30GF-100RCA. The DS30-GF-100RCA mix displayed moisture content that is the highest with $14.6 \%$ at 28 -days, $12 \%$ at 90 -days that have been $14.7 \%$, and $23.9 \%$ higher than with the PW30-GF-100RCA mix. The large quantities of organic wastewater existing in DSW contribute to the establishment of large numbers of small pores resulting in higher water absorption. The water is consumed by such waste during the mixing process and then emitted during concrete casting, which increases the ratio of water to cement (W/C) and thus decreases the concrete density (72). When tested at 28 and 90-days correspondingly, the water absorption values of the SS30-GF-100RCA mix were $8 \%$ and $22.8 \%$ higher than PW30-GF-100RCA. Water absorption was enhanced by $11 \%$ at 28 -days, and by $17 \%$ at 90 -days while mixing with SFW. While using LFW in the mixing of concrete, water absorption enhanced by $6.5 \%$ and $11.7 \%$ at 28 and 90 -days, respectively as related to the control mix. As previous studies have shown, water absorption has been increased by using various forms of wastewater in concrete mixes (33). The reduced water absorptions of FGRAC mixes may be attributed to the reason that the addition of fly ash helps to reduce the water absorption of concrete by filling the voids between the fine aggregates and the binder matrix but the addition of glass fibers and the use of RCA increases the water absorption due to high water absorption of RCA and the enhancement in the length of microchannels in the microstructure of concrete (44).

\subsection{Chloride penetration}

In this study, chloride penetration of concrete is studied using $4 \% \mathrm{NaCl}$. The method used to calculate this parameter is the penetration of ions color in millimeters penetrated by the chloride ions into the concrete microstructure. Figure 7 indicates the values of chloride ions penetration for all types of FGRAC mixes. The highest chloride penetration values were given by the FFW, which is rich in chloride iron and sulfate ions.

The control mix portrayed a chloride penetration of $11.87 \mathrm{~mm}$ at 28-days, and $7.45 \mathrm{~mm}$ at 90 -days. At 28 and 90-days, the TF30-GF-100RCA mix displayed chloride penetration that was $12.6 \%$ higher and $18.9 \%$ higher than PW30-GF-100RCA. This depicts the TF30-GF-100RCA mix as more vulnerable to oxidation and steel bar corrosion. Also, penetration of chloride indicated by the FF30-GF-100RCA blend was $14.23 \mathrm{~mm}$ in 28-days and $10.41 \mathrm{~mm}$ in 90-days. Chloride ion penetration is also enhanced by the pretty low $\mathrm{pH}$ value of FFW (70). The increased values of chloride penetration to FGRAC mixes may be ascribed to the high water absorption of RCA and the addition of glass fibers causing a balling and bridging effect between the binder matrix leaving more voids to absorb chloride ions. But the addition of fly ash is advantageous to resist the penetration of chloride ions by filling the microstructure of concrete.

Fewer iron quantities in the DSW resulted in the chloride penetration values being close to the control mix. The chloride penetration shown by the SS30-GF-

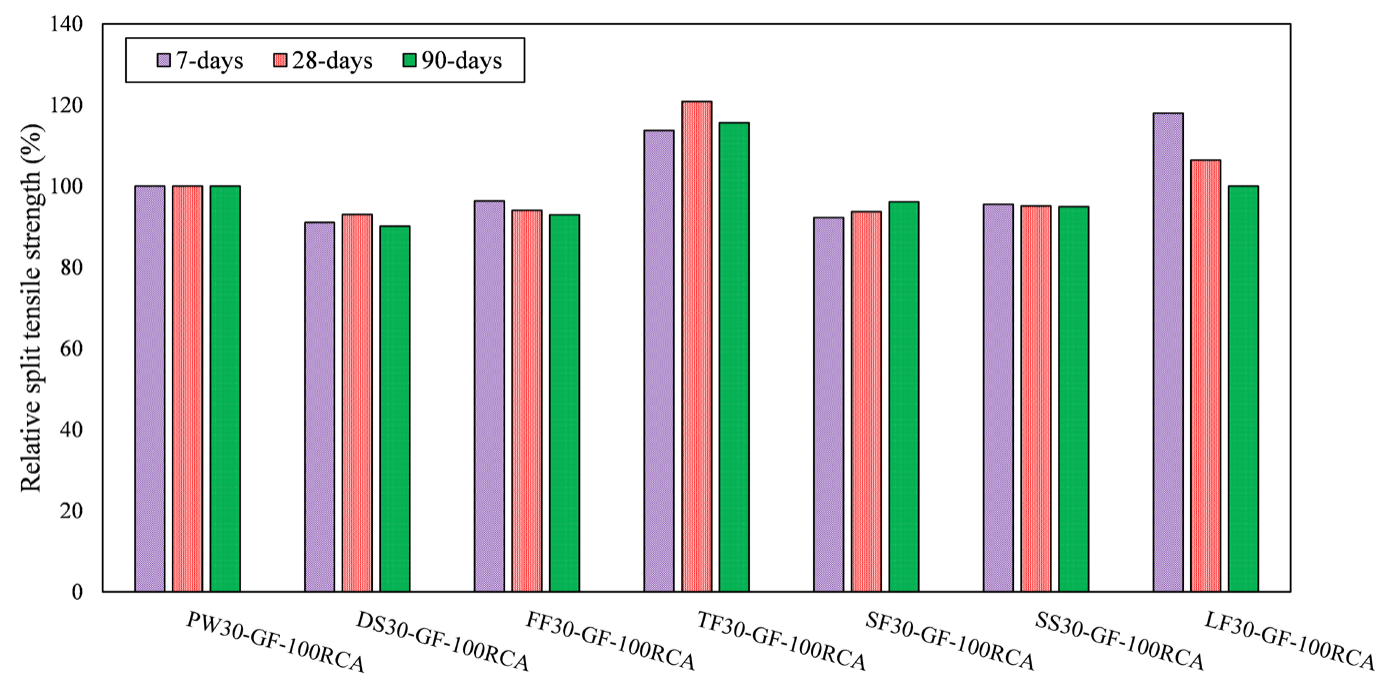

FIGURE 5. Relative split tensile strengths of FGRAC mix at 7, 28, and 90-days. 


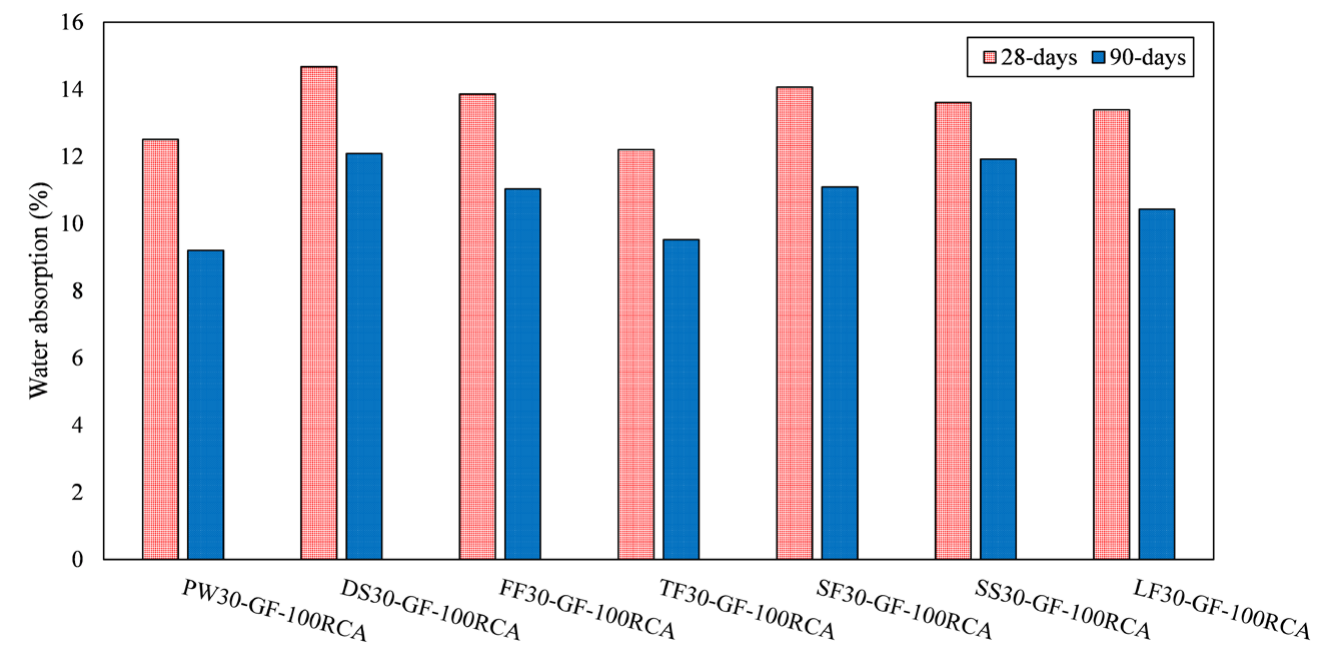

FigURE 6. Water absorption of FGRAC mixes at 28 and 90-days.

100RCA blend was $13.37 \mathrm{~mm}$ and $9 \mathrm{~mm}$ at $28-$ and 90-days, which is $11.2 \%$ and $17.2 \%$ higher on average than PW30-GF-100RCA values. The SF30-GF100RCA mix demonstrated chloride penetration values close to those of the SS30-GF-100RCA mix. Similarly, the LF30-GF-100RCA mix depicted higher values of chloride ion penetration (12.24 $\mathrm{mm}$ at 28-days and 9.64 $\mathrm{mm}$ at 28 -days) that were $3 \%$ and $22.7 \%$ higher than the control mix at 28 and 90-days, respectively. Hence, the chloride ion penetration represented by DSW was the lowest from all forms of wastewater tested, which indicates that it is less prone to corrosion.

\subsection{Acid attack resistance}

This study examined the mass loss of test samples at 28,90, and 120-days after soaking them in $4 \%$ of the $\mathrm{H}_{2} \mathrm{SO}_{4}$ solution. Figure 8 indicates the mass losses caused by each of the FGRAC mixes. The highest degradation was observed by the FF30-GF-100RCA mix.

The degradation of the TF30-GF-100RCA mix is quicker than the control mix. TF30-GF-100RCA mix reported mass losses of $6.28 \%$ after 28 -days, $13.11 \%$ after 90-days, and 16\% after 120-days, which were $30.2 \%, 23.3 \%$, and $15.8 \%$ higher than the PW30-GF100RCA mix. The FF30-GF-100RCA mix reported mass 1 losses of $7.3 \%$ at 28 -days, $14.89 \%$ at 90 -days, and $17.86 \%$ at 120 -days that were $40 \%, 32.5 \%$, and $24.5 \%$ higher than the PW30-GF-100RCA mix. The largest mass loss of the FF30-GF-100RCA mix can be linked to the lowest $\mathrm{pH}$ value $(73,74)$. Concrete deterioration is thus largely influenced by the $\mathrm{pH}$ value of both acid and wastewater mixing (75). Also, the greater mass loss can be due to the sulfate-rich FFW. The DS30-GF-100RCA mix exhibited higher degradation in the initial stages, but the degradation became identical to that of PW30-GF-100RCA at 90 and 120days. The SF30-GF-100RCA mix displayed mass losses of $5.2 \%$ at 28 -days, $12 \%$ at 90 -days, and $15.4 \%$ at 120-day testing that were higher due to the sulfuric acid $\left(\mathrm{H}_{2} \mathrm{SO}_{4}\right)$ invasion. The mass loss of LF30-GF100RCA was observed to be $5.2 \%, 11 \%$, and $14.4 \%$ at 28, 90, and 120-days, correspondingly. These mass losses were $15.6 \%, 9.2 \%$, and $6.1 \%$ higher than that of the PW30-GF-100RCA mix. So, we can say that with the use of all the various forms of wastewater examined, the degradation of concrete becomes more rapid. Figure 9 records the relative mass losses of diverse concrete mixes at various testing ages due to an acid attack as compared with the control mix. The increased values of mass losses of FGRAC mixes may be attributed to the addition of glass fibers causing a bridging effect between the binder matrix leaving more voids to absorb chloride ions. But the addition of fly ash is advantageous to resist the acid attack by filling the microstructure of concrete.

\subsection{Statistical analysis}

Tables 6-10 demonstrate the ANOVA analysis at a significance level of $5 \%$ used to assess the importance of the discrepancies between the various durability properties of the FGRAC mixes at 90-days and the mechanical behavior at 28 testing days. The FGRAC mix was split into six groups of wastewater concrete mixes (TF30-GF-100RCA, FF30-GF100RCA, DS30-GF-100RCA， SS30-GF-100RCA, SF30-GF-100RCA, and LF30-GF-100RCA) and a control mix PW30-GF-100RCA. A comparison was made between FGRAC mixes and the control mix (PW30-GF-100RCA) to explain the impact of the experimental outputs precisely.

The findings of the ANOVA test indicate that different FGRAC mixes did not show a substantial difference at 28-days of testing $\left(P=32.9 \%\right.$ and $\left.F<F_{c r i t}\right)$ between their compressive strengths at 28-days of testing, showing that the types of wastewater tested directly did not influence the compressive strength 


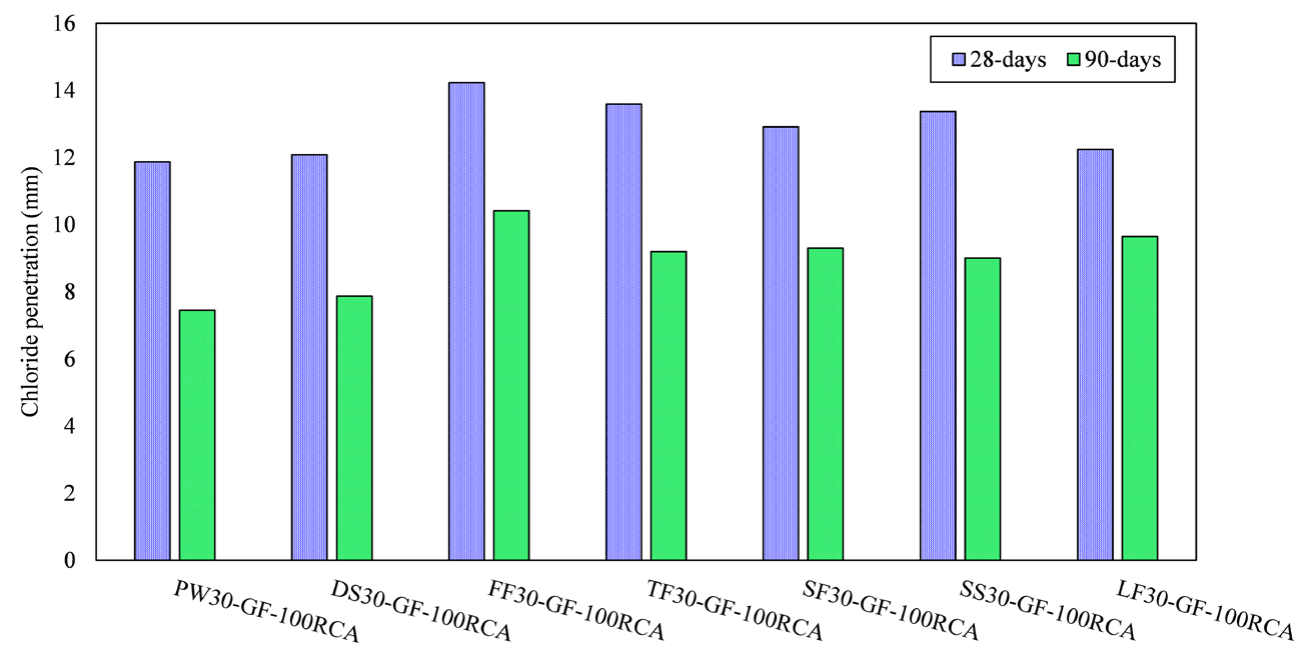

FigURE 7. Chloride penetration in FGRAC mixes at 28 and 90-days.

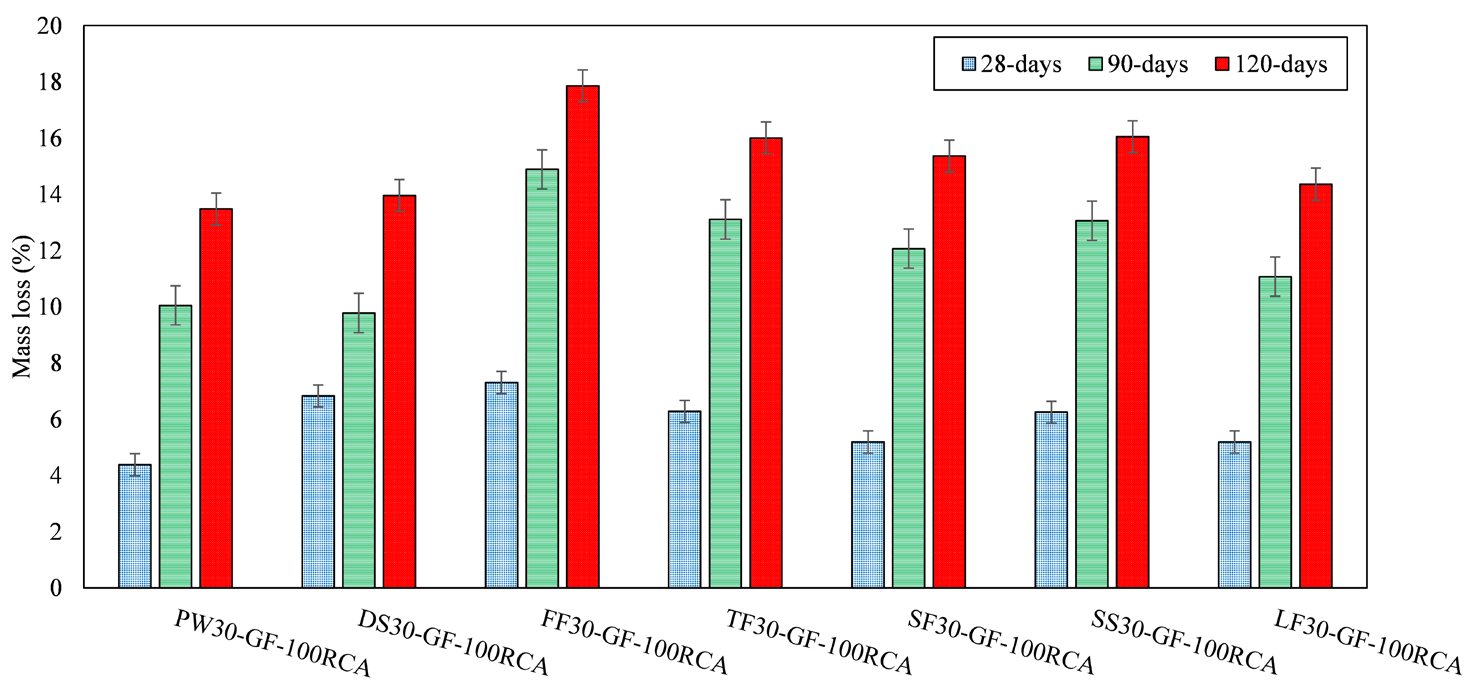

FIGURE 8. Reduction in the mass of FGRAC mixes due to the attack of sulfuric acid at various days.

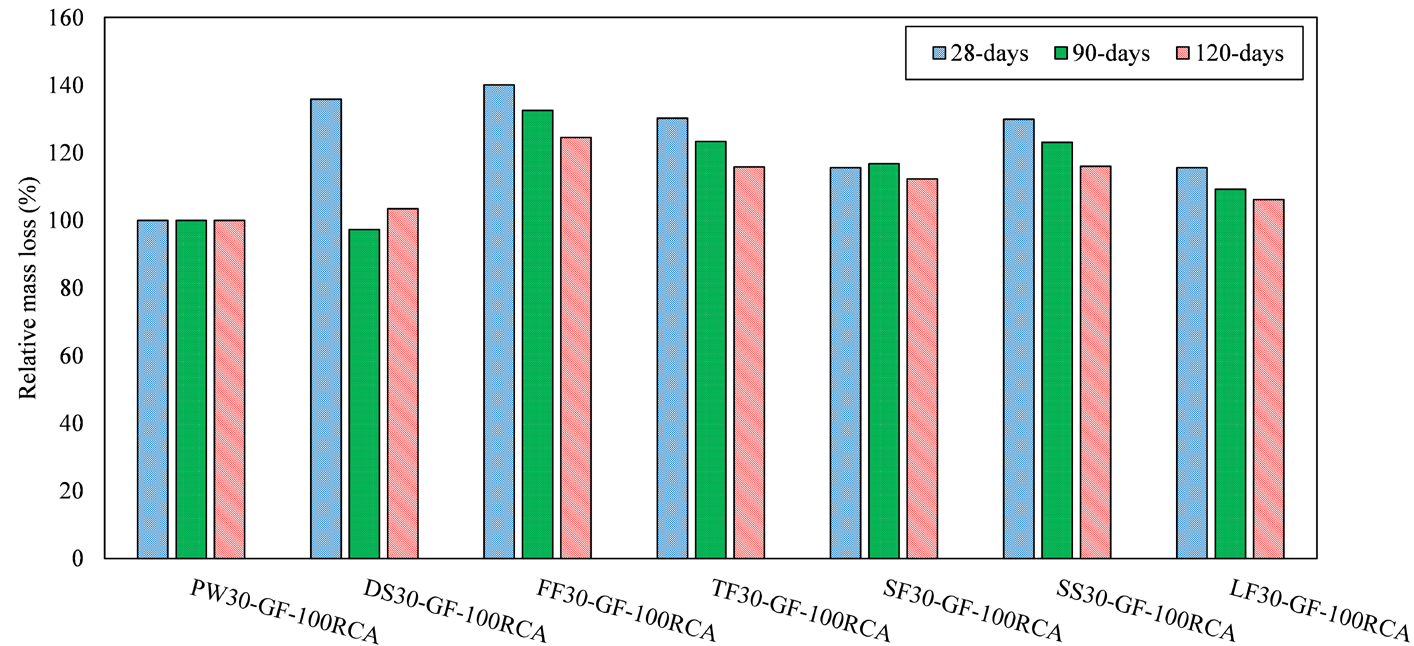

FigURE 9. Relative mass loss of FGRAC mixes at 28, 90, and 120-days. 
TABLE 6. ANOVA results for the compressive strength of FGRAC mixes at 28-days.

\begin{tabular}{|c|c|c|c|c|c|c|}
\hline Groups & Counts & Sum & Average & Variance & & \\
\hline PW30-GF-100RCA & 3 & 78.1500 & 26.0500 & 66.560643 & & \\
\hline DS30-GF-100RCA & 3 & 54.1462 & 18.0487 & 67.912354 & & \\
\hline FF30-GF-100RCA & 3 & 75.4650 & 25.1550 & 36.207506 & & \\
\hline TF30-GF-100RCA & 3 & 103.927 & 34.6425 & 128.911553 & & \\
\hline SF30-GF-100RCA & 3 & 82.0050 & 27.3350 & 72.507675 & & \\
\hline SS30-GF-100RCA & 3 & 71.83125 & 23.94375 & 24.922110 & & \\
\hline LF30-GF-100RCA & 3 & 75.5950 & 25.198333 & 0.3862583 & & \\
\hline \multicolumn{7}{|l|}{ ANOVA } \\
\hline Source of Variation & $\begin{array}{l}\text { SS (Sum of } \\
\text { squares) }\end{array}$ & $\begin{array}{c}\text { DOF } \\
\text { (Degrees of } \\
\text { freedom) }\end{array}$ & $\begin{array}{l}\text { MS (Mean } \\
\text { squares) }\end{array}$ & $\mathrm{F}$ & P-value & $\mathrm{F}_{\text {crit }}$ \\
\hline Between Groups & 434.72027 & 6 & 72.4533799 & 1.2762036 & 0.3290271 & 2.8477259 \\
\hline Within Groups & 794.81621 & 14 & 56.7725864 & & & \\
\hline Total & 1229.5364 & 20 & & & & \\
\hline
\end{tabular}

TABLE 7. ANOVA results for the split tensile strength of FGRAC mixes at 28-days.

\begin{tabular}{|c|c|c|c|c|c|c|}
\hline Groups & Counts & Sum & Average & Variance & & \\
\hline PW30-GF-100RCA & 3 & 8.535 & 2.845 & 1.6319437 & & \\
\hline DS30-GF-100RCA & 3 & 7.957 & 2.652 & 1.3675687 & & \\
\hline FF30-GF-100RCA & 3 & 8.040 & 2.680 & 0.973425 & & \\
\hline TF30-GF-100RCA & 3 & 10.810 & 3.603 & 1.6917520 & & \\
\hline SF30-GF-100RCA & 3 & 8.122 & 2.707 & 1.7310937 & & \\
\hline SS30-GF-100RCA & 3 & 8.017 & 2.672 & 1.0766437 & & \\
\hline LF30-GF-100RCA & 3 & 9.045 & 3.015 & 1.6688250 & & \\
\hline \multicolumn{7}{|l|}{ ANOVA } \\
\hline $\begin{array}{l}\text { Source of } \\
\text { Variation }\end{array}$ & S (Sum of squares) & $\begin{array}{l}\text { DOF (Degrees of } \\
\text { freedom) }\end{array}$ & $\begin{array}{l}\text { MS (Mean } \\
\text { squares) }\end{array}$ & $\mathrm{F}$ & P-value & $\mathrm{F}_{\text {crit }}$ \\
\hline $\begin{array}{l}\text { Between } \\
\text { Groups }\end{array}$ & 2.12158214 & 6 & 0.3535970 & 0.24407037 & 0.95387880 & 2.84772599 \\
\hline $\begin{array}{l}\text { Within } \\
\text { Groups }\end{array}$ & 20.2825041 & 14 & 1.4487502 & & & \\
\hline Total & 22.4040863 & 20 & & & & \\
\hline
\end{tabular}

of FGRAC. On the other hand, for the results of the tensile test, these FGRAC mixes did not display any substantial difference between them $(P=95.4 \%$ and $\left.F<F_{c r i t}\right)$, water absorption test $(P=18.64 \%$ and $F$ $\left.<F_{c r i t}\right)$, and sulfuric acid attack test $(P=22.8 \%$ and $\left.F<F_{c r i t}\right)$. The results of the chloride penetration of different FGRAC mixes have also shown no difference with $F<F_{c r i t}$ which indicates that the aspects of wastewater explored in FGRAC mixing did not influence the results of the chloride penetration.
The statistical analysis of the durability and mechanical properties of FGRAC mixes portrayed that the compressive and tensile strengths are not influenced by using different types of wastewater examined in the present work. Similarly, no significant differences in the durability properties of FGRAC mixes (water absorption, chloride penetration, and concrete mass loss due to acid attack) were observed. This statistical analysis shows that the examined types of wastewater can be employed for the mixing of con- 
TABLE 8. ANOVA results for the water absorption of FGRAC mixes at 90-days.

\begin{tabular}{|c|c|c|c|c|c|c|}
\hline Groups & Counts & Sum & Average & Variance & & \\
\hline PW30-GF-100RCA & 3 & 27.585 & 9.195 & 0.863325 & & \\
\hline DS30-GF-100RCA & 3 & 36.277 & 12.092 & 2.143481 & & \\
\hline FF30-GF-100RCA & 3 & 33.075 & 11.025 & 4.648275 & & \\
\hline TF30-GF-100RCA & 3 & 28.5675 & 9.5225 & 3.911643 & & \\
\hline SF30-GF-100RCA & 3 & 33.2775 & 11.092 & 0.343743 & & \\
\hline SS30-GF-100RCA & 3 & 35.7675 & 11.922 & 0.168882 & & \\
\hline LF30-GF-100RCA & 3 & 31.2775 & 10.425 & 2.892077 & & \\
\hline \multicolumn{7}{|l|}{ ANOVA } \\
\hline Source of Variation & $\begin{array}{l}\text { SS (Sum of } \\
\text { squares) }\end{array}$ & $\begin{array}{l}\text { DOF (Degrees of } \\
\text { freedom) }\end{array}$ & $\begin{array}{c}\text { MS (Mean } \\
\text { squares) }\end{array}$ & $\mathrm{F}$ & P-value & $\mathrm{F}_{\text {crit }}$ \\
\hline Between Groups & 22.199291 & 6 & 3.69988184 & 1.7299067 & 0.18648402 & 2.84772599 \\
\hline Within Groups & 29.942854 & 14 & 2.138775298 & & & \\
\hline Total & 52.142145 & 20 & & & & \\
\hline
\end{tabular}

TABLE 9. ANOVA results for the chloride penetration of FGRAC mixes at 90-days.

\begin{tabular}{|c|c|c|c|c|c|c|}
\hline Groups & Counts & Sum & Average & Variance & & \\
\hline PW30-GF-100RCA & 3 & 22.3545 & 7.4515 & 2.05862475 & & \\
\hline DS30-GF-100RCA & 3 & 23.6145 & 7.8715 & 2.26391025 & & \\
\hline FF30-GF-100RCA & 3 & 31.2396 & 10.4132 & 2.67804012 & & \\
\hline TF30-GF-100RCA & 3 & 27.5709 & 9.1903 & 8.68046907 & & \\
\hline SF30-GF-100RCA & 3 & 27.9069 & 9.3023 & 3.35724627 & & \\
\hline SS30-GF-100RCA & 3 & 26.9871 & 8.9957 & 0.81108867 & & \\
\hline LF30-GF-100RCA & 3 & 28.9069 & 9.6356 & 4.636279603 & & \\
\hline PW30-GF-100RCA & 3 & 22.3545 & 7.4515 & 2.05862475 & & \\
\hline \multicolumn{7}{|l|}{ ANOVA } \\
\hline Source of Variation & $\begin{array}{l}\text { SS (Sum of } \\
\text { squares) }\end{array}$ & $\begin{array}{c}\text { DOF (Degrees } \\
\text { of freedom) }\end{array}$ & $\begin{array}{c}\text { MS (Mean } \\
\text { squares) }\end{array}$ & $\mathrm{F}$ & P-value & $\mathrm{F}_{\text {crit }}$ \\
\hline Between Groups & 18.592055 & 6 & 3.0986758 & 0.88585449 & 0.53040232 & 2.84772599 \\
\hline Within Groups & 48.971317 & 14 & 3.4979512 & & & \\
\hline Total & 67.563372 & 20 & & & & \\
\hline
\end{tabular}

crete without meaningly affecting the mechanical and durability behavior of concrete.

\section{CONCLUSIONS}

The present study investigates the mechanical and durability behavior of recycled aggregate concrete incorporating with fly ash and glass fibers (FGRAC) manufactured using different categories of wastewater. One concrete mix was fabricated with potable water without adding glass fibers and fly ash for the comparative analysis. A one-way ANOVA test was carried out to study the significance of using different wastewater types, fly ash, and glass fibers on the mechanical and durability behavior of FGRAC mixes. Key points of the present study are reported below.

FGRAC mix made with textile factory wastewater represented the maximum compressive strength of $37.7 \mathrm{MPa}$ at 90 -days that was $16.8 \%$ higher than the control mix. The addition of fly ash and glass fibers 
TABLE 10. ANOVA results for the mass loss of FGRAC mixes at 90-days.

\begin{tabular}{|c|c|c|c|c|c|c|}
\hline Groups & Counts & Sum & Average & Variance & & \\
\hline PW30-GF-100RCA & 3 & 30.1428 & 10.0476 & 3.12473535 & & \\
\hline DS30-GF-100RCA & 3 & 29.3265 & 9.7755 & 4.90601475 & & \\
\hline FF30-GF-100RCA & 3 & 44.6775 & 14.8925 & 10.05263175 & & \\
\hline TF30-GF-100RCA & 3 & 39.3277 & 13.1092 & 5.591521688 & & \\
\hline SF30-GF-100RCA & 3 & 36.1961 & 12.0653 & 7.141446047 & & \\
\hline SS30-GF-100RCA & 3 & 39.1807 & 13.0602 & 8.130450563 & & \\
\hline LF30-GF-100RCA & 3 & 33.1961 & 11.0653 & 6.490071047 & & \\
\hline \multicolumn{7}{|l|}{ ANOVA } \\
\hline Source of Variation & $\begin{array}{l}\text { SS (Sum of } \\
\text { squares) }\end{array}$ & $\begin{array}{c}\text { DOF (Degrees } \\
\text { of freedom) }\end{array}$ & $\begin{array}{l}\text { MS (Mean } \\
\text { squares) }\end{array}$ & $\mathrm{F}$ & P-value & $\mathrm{F}_{\text {crit }}$ \\
\hline Between Groups & 61.0771561 & 6 & 10.179526 & 1.56825679 & 0.22813058 & 2.84772599 \\
\hline Within Groups & 90.8737424 & 14 & 6.4909816 & & & \\
\hline Total & 151.950898 & 20 & & & & \\
\hline
\end{tabular}

improved the compressive strength of FGRAC mixes by forming a CSH-gel and providing a bridging effect between the binder matrices. Correspondingly, the compressive strengths of FGRAC mixes made with FFW, SSW, SFW, and LFW were 7.8\%, 4.8\%, 7.7\%, and $7 \%$ lower than the control mix.

The highest split tensile strength was portrayed by the FGRAC mix made with textile factory wastewater with a value of $4.1 \mathrm{MPa}$ at 90 -days that was $15.6 \%$ higher than the control mix. Correspondingly, the split tensile strengths of FGRAC mixed manufactured with FFW, SSW, SFW, and LFW were 8.3\%, 3.4\%, $4.9 \%$, and $2 \%$ lower than the tensile strength of the control mix.

The FGRAC mix fabricated with domestic sewage wastewater presented the highest water absorption at 28 -days that was $23.9 \%$ higher than the water absorption of the control FGRAC mix.

The chloride penetration test portrayed that all the FGRAC mixes presented higher values of chloride ion penetrations than the control mix. Fly ash reduced the chloride penetration by forming a stronger $\mathrm{CSH}$ bond, but the addition of glass fibers increased the voids to enhance the chloride penetration.

The attack of FGRAC mixes to $4 \%$ solution of $\mathrm{H}_{2} \mathrm{SO}_{4}$ reported that all the mixes presented higher values of mass loss as compared with the control mix. The addition of glass fibers caused an enhancement in the air voids increasing mass loss. The FGRAC mix made with fertilizer factory effluent portrayed the highest value of mass loss of concrete that was $32.5 \%$ higher than that of the control mix at 120-days.

The statistical study of the testing measurements indicated no significant difference between the various mechanical and durability performance of FGRAC mixes made with different types of effluents.
Finally, it can be concluded that all types of wastewater examined in the present study can be employed for manufacturing the concrete without significantly disturbing the mechanical and durability behavior of concrete directing towards sustainable development by overcoming the carbon footprint and low tensile strength of concrete.

\section{AUTHOR CONTRIBUTIONS:}

Conceptualization: A. Raza, B. Ali. Data curation: F.U. Haq, M. Awais, M.S. Jameel. Formal analysis: A. Raza, M. Awais Investigation: A. Raza, B. Ali, M. Awais. Methodology: A. Raza, F.U. Haq. Resources: F.U. Haq, M. Awais, M.S. Jameel. Software: A. Raza, B. Ali. Validation: B. Ali, F.U. Haq, M.S. Jameel. Visualization: M. Awais. Roles/Writing, original draft: A. Raza. Writing, review \& editing: B. Ali, M. Awais, M.S. Jameel.

\section{REFERENCES}

1. McGinnis, M.; Davis, M.; de la Rosa, A.; Weldon, B.D.; Kurama, Y.C. (2017) Quantified sustainability of recycled concrete aggregates. Mag. Concr. Res. 69 [23], 1203-1211. https://doi.org/10.1680/jmacr.16.00338.

2. Coelho, A.; De Brito, J. (2012) Influence of construction and demolition waste management on the environmental impact of buildings. Wast. Manag. 32 [3], 532-541. https://doi. org/10.1016/j.wasman.2011.11.011.

3. Azúa, G.; González, M.; Arroyo, P.; Kurama, Y. (2019) Recycled coarse aggregates from precast plant and building demolitions: Environmental and economic modeling through stochastic simulations. J. Clean. Prod. 210, 1425-1434. https://doi.org/10.1016/j.jclepro.2018.11.049.

4. Xiao J.; Chunhui, W.; Ding, T.; Akbarnezhad A. (2018) A recycled aggregate concrete high-rise building: structural performance and embodied carbon footprint. J. Clean. Prod. 199, 868-81. https://doi.org/10.1016/j.jclepro.2018.07.210.

5. Silva, R.V; De Brito, J.; Dhir, R.K. (2018) Fresh-state performance of recycled aggregate concrete: A review. Construc. Build. Mat. 178, 19-31. https://doi.org/10.1016/j. conbuildmat.2018.05.149.

6. Ozbakkaloglu, T.; Gholampour, A. (2018) Time-dependent 
and long-term mechanical properties of concretes incorporating different grades of coarse recycled concrete aggregates. Eng. Struct. 157, 224-234. https://doi. org/10.1016/j.engstruct.2017.12.015.

7. More, A.B.; Ghodake, R.B.; Nimbalkar, H.N.; Chandake, P.P., Maniyar, S.P.; Narute, Y.D. (2014) Reuse of treated domestic wastewater in concrete - a sustainable approach. Ind. J. of Appl. Res. 4 [4], 182 - 184. Retrieved from https://www. worldwidejournals.com/indian-journal-of-applied-research(IJAR)/article/reuse-of-treated-domestic-waste-water-inconcrete-andndash-a-sustainable-approach/MzU0MA=/?is=1.

8. Al-Jabri, K.S.; Al-Saidy, A.H.; Taha, R; Al-Kemyani, A.J. (2011) Effect of using wastewater on the properties of high strength concrete. Proc. Eng. 14, 370-376. https://doi. org/10.1016/j.proeng.2011.07.046.

9. Nishida, T.; Otsuki, N.; Ohara, H.; Garba, Z.; Nagata, T. (2013) Some considerations for the applicability of sea water as mixing water in concrete. In: 3rd Inter. Conf. Sust. Const. Mat. Tech., Japan. Retrieved from http://www.claisse. info/2013\%20papers/data/e056.pdf.

10. Hassani, M.S.; Asadollahfardi, G.; Saghravani, S.F.; Jafari, S.; Peighambarzadeh, F.S. (2020) The difference in chloride ion diffusion coefficient of concrete made with drinking water and wastewater. Construc. Build. Mat. 231, 117182. https://doi.org/10.1016/j.conbuildmat.2019.117182.

11. Verian, K.P.; Ashraf, W.; Cao, Y. (2018) Properties of recycled concrete aggregate and their influence in new concrete production. Res. Cons. Rec. 133, 30-49. https://doi. org/10.1016/j.resconrec.2018.02.005.

12. Kisku, N.; Joshi, H.; Ansari, M.; Panda, S.K.; Nayak, S.; Dutta, S.C. (2017) A critical review and assessment for usage of recycled aggregate as sustainable construction material. Construc. Build. Mat. 131, 721-740. https://doi. org/10.1016/j.conbuildmat.2016.11.029.

13. Xiao, J.; Li, W.; Fan, Y.; Huang, X. (2012) An overview of study on recycled aggregate concrete in China (1996-2011). Construc. Build. Mat. 31, 364-383. https://doi.org/10.1016/j. conbuildmat.2011.12.074.

14. González-Taboada, I.; González-Fonteboa, B.; MartínezAbella, F.; Carro-López, D. (2016) Study of recycled concrete aggregate quality and its relationship with recycled concrete compressive strength using database analysis. Mater. Construcc. 66 [323], e089. https://doi.org/10.3989/ mc.2016.06415

15. McNeil, K.; Kang, T.H.-K. (2013) Recycled concrete aggregates: A review. Int. J. Conc. Struc. Mat. 7, 61-69. https://doi.org/10.1007/s40069-013-0032-5.

16. Rahal, K. (2007) Mechanical properties of concrete with recycled coarse aggregate. Buil. Env. 42 [1], 407-415. https:// doi.org/10.1016/j.buildenv.2005.07.033.

17. Dabhade, A.; Choudhari, S.; Gajbhiye, A. (2012) Performance evaluation of recycled aggregate used in concrete. Int. J. Eng. Res. App. 2 [4], 1387-1391.

18. Etxeberria, M.; Vázquez, E.; Marí, A.; Barra, M. (2007) Influence of amount of recycled coarse aggregates and production process on properties of recycled aggregate concrete. Cem. Conc. Res. 37 [5], 735-742. https://doi. org/10.1016/j.cemconres.2007.02.002.

19. Mukharjee, B.B.; Barai, S.V. (2014) Influence of nanosilica on the properties of recycled aggregate concrete. Construc. Build. Mat. 55, 29-37. https://doi.org/10.1016/j. conbuildmat.2014.01.003.

20. Li, W.; Xiao, J.; Sun, Z.; Kawashima, S.; Shah, S.P. (2012) Interfacial transition zones in recycled aggregate concrete with different mixing approaches. Construc. Build. Mat. 35, 10451055. https://doi.org/10.1016/j.conbuildmat.2012.06.022.

21. Huda, S.B.; Shahria Alam, M. (2015) Mechanical and freezethaw durability properties of recycled aggregate concrete made with recycled coarse aggregate. J. Mat. Civ. Eng. 27 [10], 04015003. https://doi.org/10.1061/(ASCE)MT.19435533.0001237

22. Duan, Z.H.; Poon, C.S. (2014) Properties of recycled aggregate concrete made with recycled aggregates with different amounts of old adhered mortars. Mat. Des. 58, 1929. https://doi.org/10.1016/j.matdes.2014.01.044.

23. González-Fonteboa, B.; Seara-Paz, S.; De Brito, J.; González-Taboada, I.; Martínez-Abella, F.; Vasco-Silva, R.
(2018) Recycled concrete with coarse recycled aggregate. An overview and analysis. Mater. Construcc. 68 [330], e151. https://doi.org/10.3989/mc.2018.13317.

24. Rattanachu, P; Karntong, I; Tangchirapat, W; Jaturapitakkul, C; Chindaprasirt, P. (2018) Influence of bagasse ash and recycled concrete aggregate on hardened properties of highstrength concrete. Mater. Construcc. 68 [330], e158. https:// doi.org/10.3989/mc.2018.04717.

25. Sánchez Roldán, Z.; Valverde Palacios, I.; Valverde Espinosa, I.; Martín-Morales, M. (2020) Microstructural analysis of concretes manufactured with recycled coarse aggregates presoaked using different methods. Mater. Construcc. 70 [339], e228. https://doi.org/10.3989/mc.2020.16919.

26. Shekarchi, M.; Yazdian, M.; Mehrdadi, N. (2012) Use of biologically treated domestic waste water in concrete. Kuw. Jour. Sci. Eng. 39 [2B], 97 - 111. Retrieved from http://apc. ku.edu.kw/jer/files/30Jan20131206585-use\%20of.pdf.

27. Asadollahfardi, G.; Asadi, M.; Jafari, H.; Moradi, A.; Asadolllahfardi, R. (2015) Experimental and statistical studies of using wash water from ready-mix concrete trucks and a batching plant in the production of fresh concrete. Constr. Build. Mater. 98, 305-314. https://doi.org/10.1016/j. conbuildmat.2015.08.053

28. Asadollahfardi, G.; Tahmasabi, G.; Nabi, S.M.; Pouresfandyani, H.; Hossieni, S.A.A. (2017) Effects of using concrete wash water on a few characteristics of new concrete. Envir. Eng. Manag. J. 16 [7], 1569-1575.

29. Wasserman, B. (2012) Wash water with the mix: effects on the compressive strength of concrete. Int. J. Constr. Ed. Res. 8 [4], 301-316. https://doi.org/10.1080/15578771.2011.633974.

30. Nikhil, T.R.; Sushma, R.; Gopinath, S.M.; Shanthappa, B.C. (2014) Impact of water quality on strength properties of concrete. Indian J. Appl. Res. 3 [7], 197-199. Retrieved from https://www.worldwidejournals.com/indian-journal-of-appliedresearch-(IJAR)/article/impact-of-water-quality-on-strengthproperties-of-concrete/NDI0OA $=/$ ? is $=1 \& \mathrm{~b} 1=225 \& \mathrm{k}=57$.

31. Rabie, G.; Hisham A.E.; Rozaik, E.H. (2019) Influence of using dry and wet wastewater sludge in concrete mix on its physical and mechanical properties. Ain Sham. Eng. J. 10 [4], 705-712. https://doi.org/10.1016/j.asej.2019.07.008.

32. Roychand, R.; Pramanik. B.K.; Zhang, G.; Setunge S. (2020) Recycling steel slag from municipal wastewater treatment plants into concrete applications - A step towards circular economy. Res. Cons. Rec. 152, 104533. https://doi. org/10.1016/j.resconrec.2019.104533.

33. Saxena, S.; Tembhurkar, A.R. (2019) Developing biotechnological technique for reuse of wastewater and steel slag in bio-concrete. J. Clean. Prod. 229, 193-202. https:// doi.org/10.1016/j.jclepro.2019.04.363.

34. Kou, S.; Poon, C.; Agrela, F. (2011) Comparisons of natural and recycled aggregate concretes prepared with the addition of different mineral admixtures. Cem. Conc. Comp. 33 [8], 788795. https://doi.org/10.1016/j.cemconcomp.2011.05.009.

35. Kurda, R, de Brito, J.; Silvestre, J.D. (2019) Water absorption and electrical resistivity of concrete with recycled concrete aggregates and fly ash. Cem. Conc. Comp. 95, 169-182. https://doi.org/10.1016/j.cemconcomp.2018.10.004

36. Kurda, R.; de Brito, J.; Silvestre, J.D. (2017) Influence of recycled aggregates and high contents of fly ash on concrete fresh properties. Cem. Conc. Comp. 84, 198-213. https://doi. org/10.1016/j.cemconcomp.2017.09.009.

37. Kurda, R.; de Brito, J.; J.D. Silvestre, (2018) Indirect evaluation of the compressive strength of recycled aggregate concrete with high fly ash ratios. Mag. Concr. Res. 70 [4], 204-216. https://doi.org/10.1680/jmacr.17.00216.

38. Kurda, R; Silvestre, J.D.; de Brito, J; Ahmed, H.(2018) Optimizing recycled concrete containing high volume of fly ash in terms of the embodied energy and chloride ion resistance. J. Clean. Prod. 194, 735-750. https://doi. org/10.1016/j.jclepro.2018.05.177.

39. Rashidian-Dezfouli, H.; Rangaraju, P. (2017) Comparison of strength and durability characteristics of a geopolymer produced from fly ash, ground glass fiber and glass powder. Mater. Construcc. 67 [328], e136. https://doi.org/10.3989/ mc.2017.05416.

40. Mis, H.; Güner, E.D.; Güner, H; Gökçe, N. (2020) A study on industrial-scale waste utilization in construction material 
production: the use of fly ash in GRP composite pipe. Mater. Construcc. 70 [340], e234. https://doi.org/10.3989/ mc.2020.12719.

41. Kurad, R.; Silvestre, J.D.; de Brito, J.; Ahmed, H. (2017) Effect of incorporation of high volume of recycled concrete aggregates and fly ash on the strength and global warming potential of concrete. J. Clean. Prod. 166, 485-502. https:// doi.org/10.1016/j.jclepro.2017.07.236.

42. Liu, K.; Yan, J.; Zou, C. (2018) Behaviour of recycled aggregate concrete under combined compression and shear stresses. Mater. Construcc. 68 [331], e162. https://doi. org $/ 10.3989 / \mathrm{mc} .2018 .06217$

43. Ali, B.; Qureshi, L.A. (2019) Influence of glass fibers on mechanical and durability performance of concrete with recycled aggregates. Construc. Build. Mat. 228, 116783. https://doi.org/10.1016/j.conbuildmat.2019.116783.

44. Ali, B.; Qureshi, L.A.; Shah, S.H.A.; Rehman, S.U.; Hussain, I.; Iqbal, M. (2020) A step towards durable, ductile and sustainable concrete: Simultaneous incorporation of recycled aggregates, glass fiber and fly ash. Construc. Build. Mat. 251, 118980. https://doi.org/10.1016/j. conbuildmat.2020.118980.

45. Koushkbaghi, M.; Kazemi, M.J.; Mosavi, H.; Mohseni, E. (2019) Acid resistance and durability properties of steel fiberreinforced concrete incorporating rice husk ash and recycled aggregate. Construc. Build. Mat. 202, 266-275. https://doi. org/10.1016/j.conbuildmat.2018.12.224

46. Santillán, L.R.; Locati, F.; Villagrán-Zaccardi, Y.A.; Zega, C.J. (2020) Long-term sulfate attack on recycled aggregate concrete immersed in sodium sulfate solution for 10 years. Mater. Construcc. 70 [337], e212. https://doi.org/10.3989/ mc.2020.06319

47. Zhang, Y.; Yan, L.; Wang, S.; Xu, M. (2019) Impact of twisting high-performance polyethylene fibre bundle reinforcements on the mechanical characteristics of high-strength concrete. Mater. Construcc. 69 [334], e184. https://doi.org/10.3989/ mc. 2019.01418

48. Alberti, M.G.; Enfedaque, A.; Gálvez, J.C.; Picazo, A. (2020) Recent advances in structural fibre-reinforced concrete focused on polyolefin-based macro-synthetic fibres. Mater. Construcc. 70 [337], e206. https://doi.org/10.3989/ mc. 2020.12418

49. Xie, J.; Huang, L.; Guo, Y.; Li, Z.; Fang, C.; Li, L.; Wang, J. (2018) Experimental study on the compressive and flexural behaviour of recycled aggregate concrete modified with silica fume and fibres. Construc. Build. Mat. 178, 612-623. https:// doi.org/10.1016/j.conbuildmat.2018.05.136.

50. ASTM-C150/C150M-18, Standard specification for Portland cement, ASTM International, West Conshohocken, PA. 2018. Retrieved from https://www.astm.org/DATABASE.CART/ HISTORICAL/C150C $150 \mathrm{M}-18 . \mathrm{htm}$

51. ASTMC33/C33M-18, Standard specification for concrete aggregates, ASTM International, West Conshohocken, PA. 2018. Retrieved from https://standards.globalspec.com/ std/10290845/astm-c33-c33m.

52. Bian, J.; Cao, W.; Zhang, Z.; Qiao, Q. (2020) Cyclic loading tests of thin-walled square steel tube beam-column joint with different joint details. Structures. 25, 386-397. https://doi. org/10.1016/j.istruc.2020.03.027.

53. Yang, J.; Guo, T.; Chai, S. (2020) Experimental and numerical investigation on seismic behaviours of beamcolumn joints of precast prestressed concrete frame under given corrosion levels. 2020. Structures, 27, 1209-1221. https://doi.org/10.1016/j.istruc.2020.07.007.

54. Attari, N.; Youcef, Y.S.; Amziane, S. (2019) Seismic performance of reinforced concrete beam-column joint strengthening by frp sheets. Structures. 20, 353-364. https:// doi.org/10.1016/j.istruc. 2019.04.007.

55. Hu, Y.; Zhao, J.; Zhang, D.; Li, Y. (2020) Cyclic performance of concrete-filled double-skin steel tube frames strengthened with beam-only-connected composite steel plate shear walls. J. Build. Eng. 31, 101376. https://doi.org/10.1016/j. jobe. 2020.101376 .

56. Won, D.; Lee, J.; Seo, J.; Kang, Y.J.; Kim, S. (2020) Hysteretic performance of column-footing joints with steel composite hollow RC columns under cyclic load. J. Build.
Eng. 29, 101165. https://doi.org/10.1016/j.jobe.2019.101165.

57. Xue, Y.; Yang, Y.; Yu, Y. (2020) Pseudostatic testing for loadcarrying capacity of precast concrete-encased steel composite columns. J. Build. Eng. 29, 101189. https://doi.org/10.1016/j. jobe.2020.101189.

58. González, J.G; Robles, D.R.; Valdés, A.J ; Morán del Pozo, J.M.; Romero, M. (2013) Influence of moisture states of recycled coarse aggregates on the slump test. Advan. Mater. Res. Trans. Tech. Publ. 72, 379-383.

59. Elmesalami, N.; Abed, F.; El Refai, A. (2020) Response of concrete columns reinforced with longitudinal and transverse BFRP bars under concentric and eccentric loading. Comp. Struct. 255, 113057. https://doi.org/10.1016/j. compstruct.2020.113057.

60. Al Najmi, L.; Abed, F. (2020) Evaluation of FRP bars under compression and their performance in RC columns. Materials. 13 [20], 4541. https://doi.org/10.3390/ma13204541.

61. Tu, J.; Gao, K.; He, L.; Li, X. (2019) Experimental study on the axial compression performance of GFRP-reinforced concrete square columns. Advan. Struct. Eng. 22 [7], 15541565. https://doi.org/10.1177/1369433218817988.

62. Chhorn, B.; Jung, W. (2020) Experimental evaluation of the tensile bonding strength of the basalt fiber-reinforced polymer-concrete interface. Advan. Struct. Eng. 23 [15], 3323-3334. https://doi.org/10.1177/1369433220934909.

63. Mehrdadi, N.; Akbarian, A.; Haghollahi, A. (2009) Using domestic treated wastewater for producing and curing concrete. J. Env. Stud. 35(50): p. 129-136.

64. Gao, X.; Yang, Y.; Deng, H. (2011) Utilization of beet molasses as a grinding aid in blended cements. Construc. Build. Mat. 25 [9], 3782-3789. https://doi.org/10.1016/j. conbuildmat.2011.04.041.

65. Akar, C.; Canbaz, M. (2016) Effect of molasses as an admixture on concrete durability. J. Clean. Prod. 112, 2374 2380. https://doi.org/10.1016/j.jclepro.2015.09.081.

66. Ali, B.; Qureshi L.A. (2019) Durability of recycled aggregate concrete modified with sugarcane molasses. Construc. Build. Mat. 229, 116913. https://doi.org/10.1016/j. conbuildmat.2019.116913.

67. Reddy, V.V; Rao, S. (2004) Effects of alkalinity present in water on strength and setting properties of fly ash concrete. CI-Premier PTE Ltd Singapore.

68. Mahasneh, B. (2014) Assessment of replacing wastewater and treated water with tap water in making concrete mix. Elect. J. Geotec. Eng. 19, 2379-2386.

69. Venkateswara Reddy, V.; Ramana, N.V.; Gnaneswar, K.; Sashidhar, C. (2011) Effect of magnesium chloride $(\mathrm{MgCl} 2)$ on ordinary Portland cement concrete.Ind.J. Sci. Tech.4 [6], 643-645. Retrieved from https://indjst.org/articles/effect-of-magnesiumchloride-mgcl2-on-ordinary-portland-cement-concrete.

70. Kucche, K.J.; Jamkar, S.S.; Sadgir, P.A. (2015) Quality of water for making concrete: A review of literature. Int. J. Sci. Res. Pub. 5 [1], 1-10. Retrieved from http://www.ijsrp.org/ research-paper-0115.php?rp=P373551.

71. Asadollahfardi, G.; Delnavaz, M.; Rashnoiee, V.; Ghonabadi, N. (2016) Use of treated domestic wastewater before chlorination to produce and cure concrete. Construc. Build. Mat. 105, 253-261. https://doi.org/10.1016/j. conbuildmat.2015.12.039.

72. Seyyedalipour, S.F.; Yousefi Kebria, D.; Dehestani, M. (2015) Effects of recycled paperboard mill wastes on the properties of non-load-bearing concrete. Int. J. Enviro. Sci. Tech. 12, 3627-3634. https://doi.org/10.1007/s13762-015-0879-x.

73. De Belie, N.; Verselder, H.J.; De Blaere, B.; Van Nieuwenburg, D.; Verschoore, R. (1996) Influence of the cement type on the resistance of concrete to feed acids. Cem. Conc. Res. 26 [11], 1717-1725. https://doi.org/10.1016/ S0008-8846(96)00155-X

74. Pavlik, V.; Unčík, S. (1997) The rate of corrosion of hardened cement pastes and mortars with additive of silica fume in acids. Cem. Conc. Res. 27 [11], 1731-1745. https://doi. org/10.1016/S0008-8846(97)82702-0.

75. O'Connell, M.; McNally, C.; Richardson, M.G. (2012) Performance of concrete incorporating GGBS in aggressive wastewater environments. Construc. Build. Mat. 27 [1], 368374. https://doi.org/10.1016/j.conbuildmat.2011.07.036. 